\title{
TAXATION AND INTERNAL MIGRATION-EVIDENCE FROM THE SWISS CENSUS USING COMMUNITY-LEVEL VARIATION IN INCOME TAX RATES
}

\section{Thomas Liebig}

OECD, Directorate for Labour, Employment and Social Affairs, Non-Member Economies and International Migration Division, F- 75775 Paris, France.

E-mail:Thomas.Liebig@oecd.org

\section{Patrick A. Puhani}

Leibniz University of Hannover, Institut für Arbeitsökonomik, Königsworther Platz 1, D-30167 Hannover, Germany; other affiliations: SIAW, University of St. Gallen, IZA, Bonn.

E-mail:Puhani@aoek.uni-hannover.de

\section{Alfonso Sousa-Poza (corresponding author)}

Department of Economics and Research Institute for Labour Economics and Labour Law, University of St. Gallen, Guisanstrasse 92, CH-9010 St. Gallen, Switzerland.

E-mail: Alfonso.Sousa-Poza@unisg.ch

\section{OCTOBER 2006}

\begin{abstract}
We investigate the relationship between income tax rate variation and internal migration for the unique case of Switzerland, whose system of determining tax rates primarily at the community level results in enough variation to permit analysis of their influence on migration. Specifically, using Swiss census data, we analyze migratory responses to tax rate variations for various groups defined by age, education, and nationality/residence permit. The results suggest that young Swiss college graduates are most sensitive to tax rate differences, but the estimated effects are not large enough to offset the revenueincreasing effect of a rise in tax rate. The migratory responses of foreigners and other age-education groups are even smaller, and reverse causation seems negligible.
\end{abstract}

JEL Classification: J61, H73

Keywords: Mobility, Immigration, Foreigners, Visa Status, Residence Permit, Taxation, Switzerland 


\section{Acknowledgment:}

This study was made possible by the provision of census data by the Swiss Federal Statistical Office, quality-of-life data by Emil Walter-Busch, house price data by the firm Wüest and Partner, and community expenditure data by the Swiss Federal Tax Administration (Eidgen. Steuerverwaltung). Thomas Liebig would also like to thank the German National Merit Foundation's Ph.D. scholarship programme for financial support.

Earlier versions of this paper were presented at the Annual Meeting of the German Economic Association in Dresden, 28 September-1 October 2004; the Annual Meeting of the European Association of Labour Economists (EALE) in Lisbon, 9-11 September 2004; the Research Seminar of the Economics Department of the OECD in Paris, 7 July 2004 and the first EUROFRAME conference on fiscal policies in the European Union in Paris, 7 June 2004. The authors are indebted to the participants of these conferences, as well as to Martine Durand, Simon Gächter, Jean-Pierre Garson, Gebhard Kirchgässner, Isabelle Joumard, John Martin, Paul O'Brien, Christoph Schaltegger, Hans Schmid, Kurt Schmidheiny, Nina Smith, Emil Walter-Busch, and Rainer Winkelmann for valuable discussions and comments. They are particularly indebted to Leonhard Becker and Björn Schumacher for excellent research assistance. All remaining errors are the sole responsibility of the authors.

At the time of writing this paper, Thomas Liebig and Alfonso Sousa-Poza were research associates at the Department of Economics and Research Institute for Labour Economics and Labour Law, University of St. Gallen, Switzerland. Patrick Puhani was visiting Darmstadt University of Technology, whose hospitality is gratefully acknowledged. Thomas Liebig is currently administrator at the OECD's International Migration and Non-Member Economies Division. This paper is a revised and extended version of the OECD Social, Employment and Migration Working Paper No. 24. The opinions expressed in this paper do not necessarily reflect those of the OECD or of its member countries. 


\section{TAXATION AND INTERNAL MIGRATION-EVIDENCE FROM THE SWISS CENSUS USING COMMUNITY-LEVEL VARIATION IN INCOME TAX RATES}

\section{INTRODUCTION}

In recent years, as increasing economic integration has lowered migration costs, particularly for those with high skills, highly skilled migration has been trending upwards, both in absolute and relative terms (OECD, 2002). At the same time, competition to attract highly skilled migrants to specific countries has been intensifying: the ongoing international division of labor and technological progress is demanding a more skilled workforce (Acemoglu, 2002), while demographic developments in industrialized countries are reducing domestic labor supplies. Because these processes are similar across most developed countries, immigration presents one possible solution for skill shortages, so several countries-including Canada, Germany, Switzerland, the United States, and the United Kingdom — have introduced schemes to attract highly qualified foreigners. Some nations, for example, have implemented tax incentives (Schön, 2003; Mahroum, 2001) like the Netherlands' 30 percent income tax allowance for foreigners. Such favorable tax schemes for immigrants also apply in Belgium, Denmark, Finland, Norway, and Sweden (see Liebig, 2004, for an overview). Yet, until recently, the specific determinants of highly skilled immigration (and therefore the competition for highly skilled migrants) have received relatively little research attention (Iredale, 1999). ${ }^{1}$

In this paper, we exploit the exceptionally large degree of Swiss communities' tax autonomy to estimate the relationship between the resulting income tax rates and migration. Using data from the entire 2000 Swiss census and income tax rates for more than 600 Swiss communities, we obtain a rich database on the migration behavior of 1.7 million Swiss heads of household between 1995 and 2000. This large sample size permits separate estimates for 18 subgroups distinguished by age, education, and nationality/residence permit.

\footnotetext{
${ }^{1}$ For a discussion of the impact of qualifications on the migration decision, see Liebig and Sousa-Poza (2004).
} 
Even though the role of income taxation on migration behavior has been extensively discussed in the theoretical literature since Tiebout's (1956) seminal contribution, empirical studies on income taxation's effects on migration are still rare (the early literature surveyed by Cebula, 1979, and Greenwood, 1985, focuses mostly on the United States, where the most important local tax rate is the property tax). This paucity applies especially to studies based on microdata and directed at the impact of skill level on fiscally induced migration (exceptions being Fox, Herzog, and Schlottman, 1989, and Knapp and White, 1992, who use an extract from the U.S. census and the National Longitudinal Survey of Youth, respectively). This deficiency can be attributed to various factors. First, tax considerations, despite influencing the net return on migration, are not its sole determinants. ${ }^{2}$ They cannot therefore be easily isolated from other factors that also determine net return, such as wages, local amenities, prices, and migration costs. In addition, labor is neither as homogeneous nor as mobile as capital. More important, the restrictions placed by host countries on the immigration of labor makes studies on the impact of tax considerations largely impossible in an international context.

In principle, it should be possible to study the internal migration of highly skilled people within the European Union, because nationals from EU countries enjoy freedom of movement throughout the Union and, despite similarities in fiscal relations both among and within countries (Joumard and Konsgrud, 2003, p. 20), tax rates vary widely. To date, however, empirical studies on the EU have concentrated on capital taxes, whose effects on labor migration are fundamentally different from those of income tax differences because capital's mobility costs are considerably lower and, despite a possible home-country bias in capital flows, preferences play a lesser role. In addition, cultural, linguistic, and other differences between EU countries are generally too large for the impact of a particular factor like taxation on migration to be isolated, particularly if based on aggregated data.

Such obstacles, however, can be overcome by a focus on internal migration in the few countries with a decentralized tax structure. Among these, Switzerland stands out as having the largest variation of

2 According to the human capital theory of migration introduced by Sjaastad (1962), the migration decision is determined by the net discounted return to migration. For an overview of migration models, see, for example, Massey et al. (1993). 
income tax rates at the subcentral level. Indeed, some of the most prominent empirical studies on fiscally induced migration, particularly those of Feld (2000), Feld and Kirchgässner (2001), and Kirchgässner and Pommerehne (1996), were conducted using Swiss data. Yet these three studies, being based on aggregated data, do not distinguish between age, skill and nationality/permit status groups. Therefore, an analysis using microdata allows for control of the individual characteristics determining the migration decision.

\section{TAXATION'S INFLUENCE ON MIGRATION}

Tiebout (1956) has argued that, when competing local governments offer differing tax and expenditure packages, ${ }^{3}$ sufficiently mobile individuals will migrate to the community with the tax/expenditure package that corresponds to their preferences. Conversely, in equilibrium, when there emerges an efficient allocation of resources, no individuals can improve their utility by moving to another community. Nonetheless, a Tiebout equilibrium may arise only if taxes are used to finance public goods and are not aimed at redistributing income (see also, Hansen and Kessler, 2001). ${ }^{4}$ Moreover, because the Tiebout model ignores the fact that most jobs are bound to a specific workplace, it should only apply to agglomerations. Thus, for any given job, Tiebout-type migration should only occur within commuting distance (Mieszowski and Zodrow, 1989).

Oates (1969) has argued for the capitalization of differences in taxes and local public goods in community property values. Whereas both theoretical and empirical arguments exist for a less than full capitalization of fiscal differences, particularly income taxes, in housing and property values, ${ }^{5}$ any instantaneous capitalization of community tax burden changes into property prices would inhibit taxinduced migration.

In a Tiebout setting with capitalization of taxes and local public goods into property prices, migration should occur only under two circumstances: the individual's preference structure changes (e.g., because of changing age or education) and/or the equilibrium is disrupted by changes in community fiscal policies.

\footnotetext{
${ }^{3}$ The original model was nonformal but has received formalisation and adaptation in the work of Oates (1972) and others. An overview of the Tiebout literature is provided in Dowding and John (1994).

${ }^{4}$ Of course, if redistribution is part of an individual's utility function, (some) redistribution does not prevent a Tiebout equilibrium without fiscally induced migration.

${ }^{5}$ See Feld, 2000, for an overview.
} 
This latter is of importance in Switzerland where, despite tax harmonization efforts at the federal level, community adjustment of fiscal policies increases tax rate dispersion across cantons (OECD, 1999a). Indeed, the authors' own calculations using Federal Tax Administration data show that on average, between 1995 and 2000, the tax burden at the community level declined but the standard deviation increased. Thus, it is conceivable that the growing dispersion in tax rates has influenced migration flows.

Within the literature, myriad separate studies on the determinants of migration focus on particular aspects of the migration decision (see the survey by Ghatak, Levine, and Price, 1996). Likewise, a substantial amount of both theoretical and empirical literature addresses the economic effects of tax variation for individuals and households (for overviews, see Feld, 2000; Wilson, 1999). ${ }^{6}$ Yet very few empirical studies on tax variation between (local) governments focus on income tax rate differences, probably because only a few OECD countries give local authorities substantial autonomy in public expenditure and only Switzerland provides both this autonomy and highly dispersed income tax rates at the subnational level. ${ }^{7}$

As a result, prior empirical studies on fiscally induced migration have focused primarily on the redistributive effects of tax variation and the effect on the provision of public goods at the subcentral level (see Cremer et al., 1996; Dowding and John, 1994). These studies, however, have failed to produce conclusive results. $^{8}$

The earliest study in the Swiss context dates back to Frey (1981), whose study of migration in the Basle region provides no evidence for an impact of tax rates on migration. Similarly, Feld's (2000) analysis of aggregate migration flows among Swiss cantons and major cities fails to strongly support the hypothesis of fiscally induced migration at that level. By regressing the shares of income groups across cantons on cantonal tax burden, industry, and infrastructure, Kirchgässner and Pommerehne (1996) find

6 The following section is based partly on Liebig and Sousa-Poza (2006).

7 Because several countries, including the United States, have substantial variations in local property taxes, various empirical studies address this type of tax variation, including Brett and Pinkse (2000); Brueckner and Saavedra (2001); Revelli (2002).

${ }^{8}$ One exception to the lack of research on the personal income tax-international migration link is the crosscountry analysis of Razin, Sadka, and Swagel (2002), who conclude that a higher share of immigrants in the population leads to a lower tax rate on labor income. Nonetheless, their study relies on aggregated data. 
that tax rates have an influence on the distribution of high-income earners across cantons. Feld and Kirchgässner (2001) use aggregated data from the 137 largest Swiss communities to test Tiebout's club hypothesis in a Swiss context by regressing the share of various income classes on the income tax rate. Their results provide evidence for tax effects on residential choice; that is, high earners locate to communities in which the average effective tax rates on high incomes are relatively low.

Schmidheiny (2006) criticizes these latter two approaches for neglecting the inherent endogeneity problem in aggregated data. That is, since community characteristics are themselves influenced by inhabitant choices, only community characteristics from the perspective of the individual household can be accepted as a given. Obviously, this inherent problem is a strong argument for analyses of tax competition using microdata. In fact, Schmidheiny (2006) uses household-level data on migration in the urban agglomeration of Basle in 1997. His findings suggest that rich households are significantly more likely to move to low-tax communities than poor households. Similarly, in an analysis of Swiss internal migration using the first three waves of the Swiss Household Panel, Liebig and Sousa-Poza (2006) conclude that tax burdens have no significant impact on the migration decision, which instead is primarily determined by housing-related factors.

\section{INSTITUTIONAL BACKGROUND}

The unique facets of the Swiss tax system, which reflect the country's federal structure, make the Swiss case ideal for analyzing the impact of tax variation on migration behavior. Indeed, of the OECD countries surveyed (OECD, 1999b), Switzerland has the highest share of subcentral government taxes in total government tax revenues. Only Canada (not surveyed in OECD, 1999b) has a higher share of subnational government tax receipts. However, in Canada, income taxes are primarily set at the provincial level, meaning that they account for less than 10 percent of local government tax revenues (Joumard and Kongsrud, 2003). Moreover, whereas in the U. S., which also has a decentralized tax structure, the most prominent local tax sources are property taxes, in Switzerland personal income taxes account for about 
three-quarters of local tax revenue. In the U. S., in contrast, less than 10 percent of local communities levy income taxes and the rates are generally low (Wallace and Edwards, 1999).

In Nordic countries, local governments also have large de jure discretion to set tax rates but make little effective use of this autonomy. In fact, these local governments may shun extensive tax competition to avoid jeopardizing cooperation in other areas or the discretionary features frequently exhibited by vertical government transfers (Joumard and Kongsrud, 2003). Such is not the case for Switzerland. Not only are the cantons largely autonomous in setting both the base and the rates for their income taxes, but local communities can set their own tax rates within the respective cantonal framework. Thus, because of local government's effective tax-setting autonomy, Swiss income tax rates are the most important fiscal parameter at the local level and vary widely between communities.

Admittedly, some harmonization of cantonal tax structures was achieved in 2000 and 2001; however, this harmonization covered mainly tax bases and time of taxation. ${ }^{9}$ As a result, for each of the almost 3,000 communities, different tax rates still apply and dispersion is large. For example, in 2000, for an unmarried individual with no children who earns CHF 100,000 per year, the combined cantonal and local tax burden across Switzerland in communities with more than 2,000 inhabitants varied from CHF 8,954 in Freienbach (Canton Schwyz) to CHF22,784 in La-Chaux-de-Fonds (Canton Neuchâtel). Absolute differences in marginal tax rates are even more pronounced. In 2000, for the top income levels, total marginal rates (including all government levels) for an annual income of CHF 500,000 ranged from about 21 percent (again in Freienbach, Canton Schwyz) to more than 46 percent (in Lauterbrunn, Canton Berne). Even between communities less than $20 \mathrm{~km}$ apart, differences in average and marginal tax rates of more than 5 percentage points are quite common. These differences, together with the country's small size (only about twice that of New Jersey) and excellent low-cost public transportation (and road) system, may prompt people to change their residence solely for tax reasons while still commuting to the same job. This unique situation makes Switzerland particularly suitable for analyzing the impact of different tax rates on

\footnotetext{
${ }^{9}$ For a comprehensive overview of the Swiss tax structure, see Waldburger (2003).
} 
migration, because if tax variation matters in the context of migration, it should have a measurable impact in Switzerland.

One objective of this study is to analyze whether certain groups of residents-specifically, young people, the highly qualified, and foreigners-are particularly tax sensitive. To better understand the incentive structure for foreigners, some particularities of the Swiss immigration system should be noted. ${ }^{10}$ Non-temporary labor immigrants first enter Switzerland by means of an annual permit, the so-called B permit, which limits mobility across the country and requires approval for a change of employment or canton of residence. ${ }^{11}$ Once individuals have resided in resided in Switzerland for five years [European Economic Area (EEA) and U.S. nationals] or ten years (all other nationals) without interruption, they are generally awarded permanent residency cards ( $\mathrm{C}$ permits) that allow full mobility and assure equal treatment with Swiss nationals in the labor market. The distinction between immigrants, all individuals born abroad who did not have Swiss citizenship at the time of birth, and foreigners, all those not holding a Swiss passport, is particularly important for Switzerland, which adheres to the ius sanguis principle of parental rather than place-of-birth citizenship (ius soli). Thus, the term foreigner can apply to first, second, or subsequent generation foreigners (i.e., the latter groups being native-born offspring of the foreign-born). Consequently, in this paper we apply this citizenship concept and distinguish between foreigners (of any generation) with a permanent residency (C) permit and those with an annual (B) work permit. Note, however, that as many as 87 percent of all foreigners aged 21 to 64 are also immigrants, as native-born foreigners have the possibility to become naturalized.

Until the 1990s, Switzerland's immigration policy favored low-skilled immigration. However, since 1991, immigration has gradually become restricted to highly qualified individuals and has favored immigration from countries belonging to the European Economic Area. Holders of an annual work permit (annual laborers) are taxed at source (i.e., taxed at special rates that are uniform within cantonal

10 For a comparative description of Switzerland's immigration policy, see Liebig (2003).

11 Since 1 June 2002, not only do European Economic Area nationals enjoy full mobility within Switzerland, but their "annual" permit now lasts five years. This study, however, relies on data collected prior to this liberalization. 
communities but vary across cantons), whereas foreigners with a permanent residency permit (permanent residents) are taxed like Swiss nationals. Therefore, tax variation among different communities should not matter much for foreigners with an annual work permit. Nonetheless, if these individuals earn more than CHF 120,000, they may opt for ex-post retaxation, which results in the same tax treatment as that for Swiss citizens. Thus, tax rates should have an impact on foreigners with an annual (B) work permit earning more than CHF 120,000 and those with a permanent residency (C) permit. However, B permit holders earning less than CHF 120,000 may also relocate depending on community tax rates, because, depending on their nationality, they receive a permanent residency card after five or ten years in the country.

\section{DATA}

This analysis is conducted primarily using data from the 2000 Swiss census, which, because it covers the entire population of Switzerland, contains data on all 7.3 million Swiss residents, including almost 1.5 million foreigners. In addition, even though census data generally yield only limited information on individual migration behavior, the information-rich 2000 census records not only educational level, nationality, household characteristics, and foreigner permit category, but also-most important for an analysis of migration behavior on the microdata level - the community of residence at the time of the census and five years previously. ${ }^{12}$ The entire empirical analysis is limited to individuals aged of 21 to 64 and, to avoid biases that may occur with family migration flows, the regression analysis is limited to the head of household, defined as the person who works the most hours per week. The result is a total of 2,287,652 observations having lived in any of 2,899 communities in 1995.

Because mobility may vary over the lifecycle and according to education level and visa status, we build three age groups (21-35, 36-50, and 51-64 years of age), three education groups (without vocational education, with vocational education, and with a college degree or equivalent as the highest attainment) and three visa groups (Swiss citizens, permanent residents [C permit holders], and annual laborers [B permit holders]). Estimates are provided separately for these 27 groups. The education group definitions

\footnotetext{
13 Unfortunately, no information is available on whether people moved more than once within this period.
} 
reflect the Swiss education system, in which, as in Germany, the vocational education system (apprenticeship) plays a dominant role. Workers without vocational education are deemed unskilled; those having completed an apprenticeship, skilled; and those with college or equivalent, highly skilled. ${ }^{13}$

Statistics on community tax rates (for the years 1990, 1995, 2000, and 2005) are taken from Federal Tax Administration (Eidgenössische Steuerverwaltung) data on entities with more than 2,000 inhabitants. Having to select household heads that have lived in communities for which 1995 tax data are available (a total of 728) initially reduces the number of observations from 2,287,652 to 1,730,180 (by 24 percent), and requiring that they also have lived in a community for which 2000 tax rate data are available further reduces the number to $1,728,374$ observations. In addition, because Swiss Census data do not contain information on income, we must proxy the sampled individuals' tax rates by estimating earnings regressions from alternative data and using the coefficients to predict earnings and allocate the tax rate. Person-level earnings data are taken from the 2000 Swiss Wage Structure Survey of Switzerland's Federal Statistical Office (Lohnstrukturerhebung). This survey is addressed at employers and thus has very reliable earnings data for a large number of employees: our regression is based on about 350,000 observations. As regressors, we select variables that are defined similarly in both surveys; that is, nine age group indicators, gender, seven educational dummy variables, three nationality/visa status groups, ten industry dummies, five indicators for the degree of part-time employment, and a managerial occupation indicator. Observations with missing data are allocated sample means of the respective variables. The $\mathrm{R}^{2}$ of the earnings regression is 56 percent. Based on the predicted earnings intervals, we allocate the published tax rates for $20,25,30,40,50,60,70,80,90,100$, and 150 thousand Swiss francs (the maximum of predicted earnings is CHF 154,000).

Because the new economics of migration (Stark, 1991) has drawn attention to the importance of subjective perceptions in the migration process and social science research has indicated that quality of life is best measured by subjective evaluations (Walter-Busch, 1983; 2000), the analysis is augmented, as in

13 This breakdown corresponds roughly to high school dropouts, high school graduates, and college dropouts or college graduates in the American system. In terms of ISCED, they correspond to ISCED 0-2, ISCED 3-4 and ISCED 5-6, respectively. 
other studies (e.g., Feld and Kirchgässner, 2001), by the Walter-Busch (1997) quality of life index. This index, used for a 1996 survey of 21,242 army recruits (i.e., males of about 18 years of age) from across Switzerland, is a summary statistic from a set of 21 questions answered on a scale from 1 to 5 . These questions address issues like the architectural and natural beauty of the community, housing conditions, shopping, education, social, health, transport, administrative and childcare facilities, noise, population mentality, and economic conditions. The number of communities for which both the 1996 Walter-Busch quality of life index ${ }^{14}$ and 1995 tax rates are available is 636 (i.e., we lose 92 communities), leaving $1,620,708$ observations of household heads.

To control for objective community amenity measures, we integrate into the model both house prices and community expenditures. As regards the former, the consulting company Wüest and Partner made available their list of offered house prices per square meter for the year $2000 .{ }^{15}$ For the earlier period (1995), no such index exists, but house prices are available for all 636 communities for which we have tax and quality of life data. Thus, inclusion of these data places no additional restriction on the sample size.

Federal Tax Administration (Eidgenössische Steuerverwaltung) data on community expenditure (1995 and 2000) - comprised of nine variables related to general administration, law and order, education, culture, health, social welfare, transport, environment, and other expenditures — are only available for a selection of 123 larger communities (in 1995, primarily those with 10,000+ inhabitants). Thus, adding these data to the 1995 community tax and expenditure data, the year 2000 house prices, and the 1996 quality of life index reduces the sample size by almost half, to 916,063 household heads.

Because the variable means vary little between samples, we display the summary statistics by nationality/visa status for only one estimation sample (see Table 1), and, rather than covering all variables, our discussion focuses on certain key features. Overall, as the migration indicator shows, the migration probability for permanent residents (at 6.1 percent) is lower than that for Swiss citizens (at 8.8 percent), but the migration probability for annual laborers (B permit holders) is higher (11.1 percent, despite the

\footnotetext{
${ }^{14}$ The quality of life measure is only available for 1996 as no later surveys have yet been conducted.

15 We thank Gebhard Kirchgässner for establishing the contact with Wüest and Partner.
} 
regulatory restrictions on their mobility!). However, what this illustration does not show is that the migration probability varies even more by education and age and is 22 percent for young Swiss college graduates. As regards average tax rates, they are around 14 percent with standard deviations of around 3.4 percentage points. Between 1995 and 2000, the average tax rates decrease by about half a percentage point on average, with standard deviations of around 0.55 . It should also be noted that although the variation in community expenditures seems large, these raw figures must be seen in relation to community size. We implicitly normalize these expenditure data in our regressions by controlling for community size.

Further information on the $\mathrm{B}$ and $\mathrm{C}$ permit holders is given in Table 2, which lists the primary nationalities and their sample shares, as well as the shares of college graduates within these nationality/visa groups. Most permanent residents ( $\mathrm{C}$ permit holders) are from former guest worker countries (Italy, Portugal, Spain, former Yugoslavia) and all ten most highly represented nationalities are European (including Turkey). The share of college graduates is the highest for foreigners with German, French, or Austrian nationality. It should also be noted that the annual laborers (B permit holders) in the sample have already lived in Switzerland for five years. That is, as European Economic Area B permit holders usually receive a $\mathrm{C}$ permit after five years in the country (they must apply for it), the $\mathrm{B}$ permit sample is dominated by eastern or non-European nationalities who must reside in Switzerland for ten years before obtaining a permanent residency card. Nonetheless, with the exception of Sri Lanka, European nationalities (including Turkish) still dominate. Again, the share of highly skilled persons is highest among Germans, French, and Italians.

\section{EMPIRICAL ANALYSIS}

Our empirical analysis consists of four parts. First, we assess whether people move to low tax rate communities; second, we investigate whether high tax rate levels generate outmigration; third, we analyze the association between tax rate changes and outmigration, and finally, we address the issue of reverse causation of migration on tax rates. As no credible instrument or natural experiment exists for identifying the lines of causation, we estimate the effect of tax rate changes between 1990 and 1995 on migration 
during the following five years (1995-2000) and the effects of migration between 1995 and 2000 on 20002005 tax rate changes.

\section{Migration to Low Tax Areas}

In the first set of regressions, displayed in Table 3, we regress the migration indicator on the difference between the 1995 tax rate in 1995 community of residence and the 2000 tax rate in the 2000 community of residence. Hence, we estimate the (partial) correlation between moving and tax rate changes. A positive (partial) correlation would mean that movers experience lower tax raises (or larger tax cuts) than those who do not move. However, a positive coefficient in these regressions would not imply that rising taxes cause people to move out of their community; it is still conceivable that the decision to migrate is determined by other factors. Nonetheless, once people decide to migrate, they are likely to choose a lowtax location (see, e.g., Fox, Herzog, and Schlottman, 1989). ${ }^{16}$ In this case, taxes determine the location choice for migrants, but not migration itself. ${ }^{17}$

Table 3 displays the results of the logit regressions, which are not the logit coefficients but rather the estimated marginal "effects" of the tax difference on the probability of moving (determined at the mean values of the regressors). The standard errors below these effects are calculated using the delta method. In the remaining tables, Panel A refers to Swiss citizens, Panel B to permanent residents (C permits), and Panel C to annual laborers (B permits). For each nationality/visa group, we build nine subgroups defined by the three educational (with or without vocational education, and college or equivalent) and three age (21-35, 36-50, and 51-64) groups. These latter account for changes in the propensity to migrate over the lifecycle (see Clark and Hunter, 1992). ${ }^{18}$

\footnotetext{
${ }^{16}$ This empirical study distinguishes between migration and location choice decisions.

${ }^{17}$ In the subsequent two subsections, we investigate the migration decision itself. The location decision is out of the scope of this paper, as we lack information on taxes for communities with less than 2,000 inhabitants.

${ }^{18}$ Clark and Hunter (1992) provide evidence of variations in the migratory effects of taxes over the lifecycle using U.S. county data.
} 
Each panel presents nine models for each age/education subgroup, with results for each specification given in columns (1) to (6). Column (1) displays the results without control variables; that is, the moving indicator is regressed on the tax difference with only a constant as a further regressor. Column (2) integrates the control variables of household characteristics; namely, the age, gender, and marital status of the household head and the number of children as of 1995. Column (3) adds to these the differences in community size and Walter-Busch quality of life index between the 1995 and 2000 communities of residence. If low tax communities have a lower quality of life than high tax communities and people prefer to move to communities with a higher quality of life, all else being equal, we would expect inclusion of the quality of life index to increase the estimated association between tax differences and mobility.

A similar reasoning applies to the inclusion of house price differences between the 1995 and 2000 communities of residence. If house prices are higher in low tax communities (i.e., if there is some capitalization) and households move to areas with low house prices, all else being equal, controlling for house prices should increase the estimated coefficient on tax rate differences. However, house price data may proxy for unmeasured community amenities not reflected in the Swiss army recruit quality of life index. If so, even after quality of life as measured here is controlled for, households might prefer communities with higher house prices. In this case, controlling for house prices might decrease the estimated coefficient on taxes.

Another important variable for measuring local amenities is community expenditures. However, as explained earlier, because data on this variable are only available for larger communities, their inclusion restricts the estimation sample to persons having resided in a community with more than 10,000 inhabitants in both 1995 and 2000. Thus, by failing to measure migration from and to small communities, many of which are tax havens, this sample selection might induce a bias in the estimate. ${ }^{19}$ We illustrate this sample selection effect by displaying in column (5) the same estimate as in column (4) but for the restricted sample for which differences in 1995 and 2000 community expenditures are available. Column

${ }^{19}$ Among the communities for which we have published tax rate data, the ten entities with the lowest tax rates for people earning CHF 100,000 all have less than 23,000 inhabitants. 
(6) then estimates the association between tax differences and migration with the community expenditure variables included. From the simple omitted variable bias formula, we expect that if households prefer, ceteris paribus (i.e. for a given tax level), high expenditure communities and if high expenditures are correlated with high taxes, then the inclusion of community expenditures will increase the estimate.

Column (1) of Panel A (Swiss citizens) in Table 3 shows that for the nine subgroups, the association between the 1995-2000 tax rate decline and internal migration is mostly positive; however, it is larger for both younger than older persons and more educated than less educated persons. Specifically, the 0.037 for college graduates between 21 and 35 years of age means that a difference of one percentage point in the tax rate change is associated with an increase in the migration probability of 3.7 percentage points. To put this estimate into perspective, for college graduates aged 21 to 35 , the average migration probability in the sample is 20 percent. For college graduates aged 36 to 50 and 51 to 64 , the corresponding estimates are 1.7 and 0.6 percentage points, respectively. These estimates barely change when household characteristics (column 2) and quality of life (column 3) are controlled for. On the other hand, controlling for house prices (column 4) reduces the estimates for some groups and increases them for others. However, with the possible exception of college graduates aged 21 to 35 , for whom the estimate shrinks by about a third to 2.4 percentage points (indicating that higher house prices may be associated with quality-of-life differences for this group not measured by the subjective index), the changes are not massive. Thus, the overall finding that younger individuals react more to tax differences than older persons and more educated household heads react more than less educated ones still holds. For young persons with no vocational training, the estimate in column (4) is not only negative but also significant, which remains the case in the reduced sample (column 5) of those who have lived in communities for which both 1995 and 2000 expenditure data are available. It may be that this young, unskilled group benefits from high taxes through the expenditures they finance. Indeed, controlling for expenditures (column 6) increases the value of the estimate (i.e., reduces the absolute value, as the estimate is negative), which is consistent with the conjecture that young unskilled persons are attracted by high tax/expenditure communities. For household heads with at least vocational education, the estimates in columns (5) and (6) confirm the findings of the regressions with 
fewer control variables (columns 1 through 4). That is, the association between mobility and tax changes is greater for younger, more educated persons than for older, less educated persons.

For foreigners with a permanent residency card (Panel B of Table 3), estimates are similar, although some differences from Swiss citizens are worth noting. First, the positive, significant estimate for young persons without vocational education, shown in columns (1) through (4), does not apply for Swiss citizens. Even in the samples that include expenditure data (columns 5 and 6), this effect, while smaller, is still significant. Moreover, in the specification with expenditure data (column 6), the estimate for the youngest groups with vocational education becomes insignificant, whereas the youngest group with college education displays the largest responsiveness to tax differences just as for Swiss citizens (cf. Panel A of Table 3). For foreigners with a permanent residency card, the estimate is smaller, 1.6 versus 2.8 percentage points for Swiss citizens.

More distinctly different are the results for Swiss citizens and permanent residents versus annual work visa holders (see Panel $\mathrm{C}$ of Table 3). Even though some annual laborers may attempt to move to a low tax area before obtaining a permanent residency card, we expect these estimates to be smaller. As columns (1) through (4) of Panel C show, compared with the results given in Panel A for Swiss citizens, the estimates for young college graduates are indeed smaller (and even insignificant in column 4) for annual work visa holders than for Swiss citizens. However, the estimate for annual laborers aged 51 to 64 with vocational education in column (4) is not only positive and significant but larger than that for similarly qualified Swiss workers of the same age. This finding may result from a significant share of workers in this subgroup reaching the CHF 120,000 income threshold at this age and moving to a community with lower taxes, although such a hypothesis is not testable given the absence of personal income information in the census data (the average predicted labor income for this group is CHF 80,000). However, in the expenditure samples, this estimate becomes insignificant (columns 5 and 6), probably since persons in this 
age group move to small communities for which no expenditure data are available. ${ }^{20}$ At the same time, the positive significant estimate of 1.4 and 2.1 percentage points for young college graduates in these samples is consistent with a significant share of this age/education group selecting fiscally attractive locations before obtaining a permanent residency card.

\section{Migration Out of High Tax Communities}

Having found an association between the incidence of moving and the associated changes in community tax rates, we test for migration out of high tax areas by regressing the moving indicator on the tax rate in the 1995 community of residence. Table 4 shows the results for the same subgroups as in the previous analysis using similar control variables except for the following. First, being interested in a higher community tax rate for a given level of income rather than the effect of a higher community tax rate per se, we always control for the predicted income brackets using a set of dummy variables. Second, in the estimates outlined in columns (3) to (6), we additionally control for the quality of life index, house prices, and community expenditures in the 1995 community of residence. ${ }^{21}$ Third, we need not drop persons moving to smaller communities, only those living in smaller communities in 1995. Therefore, the sample selection problem of missing data on expenditures for smaller communities is reduced in these models.

Throughout the specifications for Swiss citizens (see Panel A of Table 4), only the coefficients for young persons (aged 21-35) with a college degree are robustly positive and statistically significant. Nonetheless, the estimates are rather small: a one percentage point higher community tax rate in 1995 increases outmigration by between 0.1 and 0.9 percentage points, with the full specification including expenditure variables rendering 0.7 percentage points. This result indicates that over a five-year horizon seven in 1,000 household heads leave the community because of a one percentage point higher tax rate. For groups other than college graduates, the estimates are either insignificant or negative at 0.1 or 0.2

${ }^{20}$ The change in average community size between 1995 and 2000 is about 5,300 persons smaller for this group in the full sample compared to the expenditure sample, meaning that we tend to lose persons moving to smaller communities when considering the expenditure sample.

${ }^{21}$ Ideally, data for all these variables should be from 1995, but as explained in the Data section, the quality of life index is only available for 1996 and the house prices for 2000. 
percentage points, as shown, for example, for persons aged 51 to 64 without vocational education for whom higher taxes may correlate with unmeasured community characteristics/expenditures that correspond to their preferences.

For permanent residency card and annual work visa holders (see Panels B and C of Table 4, respectively), no estimates remain significant at the 5 percent level in the complete specification with expenditure data (column 6). For annual laborers who only benefit from low community tax levels if they have an income above CHF 120,000, this result is less surprising. However, for permanent residents, we would have expected a positive effect. This difference may result from permanent residents having lower levels of wealth than Swiss citizens and therefore being less sensitive to tax levels than Swiss individuals of the same age, educational, and labor earnings level. ${ }^{22}$

\section{Migration Out of Communities with Rising Tax Rates}

The previous analysis of migration and tax levels may be biased if unobserved factors influencing the relative attractiveness of a community are correlated with tax levels. Therefore, even though we lack the experimental setting to ensure that tax changes are uncorrelated with unobserved community characteristics, we perform a regression analysis of migration and changes in tax rates (between 1995 and 2000). Because all specifications control for tax levels and predicted earnings brackets, we estimate the effect of tax changes holding tax levels and earnings constant. As Table 5 shows, the estimates for all subgroups of Swiss household heads (see Panel A) are significant and positive in almost all specifications. Moreover, the estimates for younger persons are always larger than those for older household heads (i.e. younger people are more inclined to migrate out of communities where taxes are rising). That is, in all specifications (1) through (6), young college graduates exhibit the largest effects of all groups, followed by young household heads with lower educational levels. Reducing the sample to those living in communities

\footnotetext{
${ }^{22}$ Note that we can only predict a person's labor earnings from the Swiss Wage Structure Survey. Additional income from capital assets is not measured and cannot be predicted, either. If Swiss citizens have on average a higher level of wealth than foreigners, they are likely to be more sensitive to tax variation for a given level of labor earnings.
} 
with available expenditure data changes little; however, controlling for community expenditures leads to a sizeable reduction in the estimated effect for most subgroups. For young persons, the estimates for specification (6) imply an increase in the migration probability of between 2.8 and 3.3 percentage points per one percentage point higher tax rate change.

For permanent residents (see Panel B of Table 5), the structure of estimates across age and education groups is in many respects similar to that for Swiss workers. However, once community expenditures are controlled for, the only significantly positive effect amounts to 3.3 percentage points young persons with vocational education. Surprisingly, with these expenditures controlled for, the effect for young college graduates is no longer significant (see specification 6).

For foreigners with an annual work visa (see Panel C), no estimates in column (6) are significant, although the point estimate for young college graduates does reach 1.9 percentage points. However, the estimate for college graduates without community expenditures as controls (column 5) is significant and the largest of all groups at 6.2 percentage points. However, as with permanent residents, this estimate becomes insignificant once community expenditures are controlled for.

\section{Directionality of Taxes and Migration}

Regressing migration on either 1995 tax rate levels or (most especially) tax rate changes between 1995 and 2000 raises the issue of reverse causality. That is, not only may rising taxes lead to outmigration, but outmigration may require rising tax rates if communal public goods must be financed by fewer residents. As no natural experiment is available for estimating directionality, we resort to a simpler method of testing for possible reverse causation. First, we regress the migration indicator on tax rate changes between 1990 and 1995 in the 1995 community of residence, and then we regress tax changes between 2000 and 2005 on the 1995-2000 outmigration rates of the nine age-education groups (see Tables 6 and 7 , respectively). 
The example estimates for Swiss citizens (Table 6), ${ }^{23}$ although somewhat lower in absolute value, are similar in structure to the tax change estimates in Table 5 (Panel A). For example, according to Table 6, a one percentage point higher tax rate change between 1990 and 1995 effects a 2.9 percentage point increase in the outmigration rate for young college graduates. The corresponding estimate in Table 5 (Panel A) is 3.3 percentage points. Obviously, being related to different time periods and thus different aspects of the migration-tax rate relationship dynamic, these results are not directly comparable.

The reverse regressions are presented in Table 7. Certain aspects of the analysis warrant further discussion. First, because communities are the decision makers, the regressions are carried out at the community level for 726, 630, and 127 entities (columns (1)-(2), (3)-(4), and (5)-(6), respectively). Second, we include the same control variables as in the previous regressions (see the table notes for details) but convert them to community sample means. Estimates are obtained by weighted least squares with year 2000 community sizes as weights. Third, the displayed coefficients refer to the outmigration (between 1995 and 2000) induced by the respective age/education subgroup. That is, unlike the previous tables that report separate regressions, every column of Table 7 reports estimates deriving from a single regression equation. Fourth, because the impact variables are not the number of outmigrants over the size of the corresponding age/education group but rather the number of outmigrants (1995-2000) over the total size of the community (1995), the estimated coefficients are comparable. That is, they all state the effect of the same increase in outmigration caused by any subgroup holding outmigration of all other groups constant.

The displayed estimates allow the following comparative analysis. First, because outmigration rates are measured in decimals and tax rate changes in percentages, we interpret the coefficient of 32.1 for young college graduates (column (1)) to mean that a 1 percentage point increase in the outmigration rate caused solely by young college graduates effects a 0.321 percentage point increase in tax rate change. To compare this estimate with the effect of tax rate changes on group-specific migration rates in Table 6 , we must multiply it by the sample share of young college graduates, which amounts to 0.088 . Hence, a one

\footnotetext{
${ }^{23}$ We provide results for Swiss citizens only to conserve space.
} 
percentage point higher outmigration rate of this group produces a $0.088 \times 0.321=0.028$ higher percentage point tax rate change. According to Table 6, column (1), a one percentage point increase in the tax rate change effects a 2.8 percentage point increase in the outmigration rate. Hence, the effect of taxes on migration seems much larger than the reverse effect. Moreover, in column (6) of Table 7, only the estimate for young persons with vocational training remains significant at the five percent level (again the effect is small).

Interestingly, at the ten percent significance level, we obtain a negative estimate for older persons (aged 51-64) without vocational education. The estimate of -101.1 suggests that an increase in the outmigration rate of one percentage point of this group reduces the tax rate change by $1.011 \times 0.071=$ 0.072 percentage points (i.e., taxes tend to decline). Although the estimated effect is again small, the finding of a negative effect is plausible if this age group is a major consumer of health and social welfare expenditures.

\section{CONCLUSIONS}

Even prior to the emerging competition for highly skilled immigrants, the impact of taxation on migration attracted much interest among economists and policy makers alike. On the one hand, it is acknowledged that fiscal federalism, by allowing fiscal policy to adjust to local preferences, may be efficiency enhancing. As a result, many OECD countries are discussing the issue of tax decentralizationwhich as Oates (1999, p. 1120) remarks "is in vogue"-and in Germany, fiscal federalism has been reformed to provide more taxation autonomy to the states (Länder). On the other hand, a major objection to such policies is the potentially negative spillover (e.g., suboptimally low rates) that may result in wasteful tax competition (e.g., for taxpayers) among local governments.

However, such tax competition will only materialize if migration is actually tax induced, a causality empirically undetermined because of little variation in internal tax rates in most countries. In the face of such a dearth, Switzerland, because of its unique system of determining income taxes primarily at the local level, provides a unique opportunity for assessing the effect of income taxation on migration. Nonetheless, 
earlier studies on tax variation in Switzerland, while generally supportive of the notion that taxes affect residential choice, have also been limited by a reliance on aggregated data.

In contrast, by using individual-level data from the 2000 Swiss Census, this study analyzes both the effects of tax rate levels and of tax rate changes. The results from separate estimates for 27 subgroups defined by three age, three education, and three nationality/visa categories indicate that tax rate effects are generally larger for younger, highly educated persons than for older, less educated individuals. Additionally, Swiss citizens seemingly react more strongly to tax rates than foreigners with permanent residency, who themselves react more strongly than foreigners with annual work visas. The findings for reverse causation from migration to tax rates (to the extent it could be analyzed) are insignificant.

One robust finding of this study is that the community tax rate has a significant impact on young Swiss college graduates. When personal characteristics, community quality of life, house prices, and expenditures are held constant, the tax level estimate suggests that a one percentage point higher tax rate leads to an outmigration of seven out of 1,000 young Swiss college graduates. Once tax rate levels are controlled for and the change in tax rate makes the impact variable, a one percentage point higher tax rate increase leads to the outmigration of 33 out of 1,000 young Swiss college graduates. Nonetheless, these estimates are relatively small: given an average tax rate of 16 percent, a one percentage point increase in tax rates for this group implies a 6.25 percent increase in community revenues. As a result, because tax rate-induced outmigration of somewhat more than 3 percent of affected persons is too small to offset the increase in revenues, community revenues will in fact rise through increased tax rates.

This latter observation casts doubt on the effectiveness of tax incentives (like those in the Netherlands and Sweden) as a means of attracting highly skilled immigrants without losing fiscal revenues. Specifically, if tax rates do not strongly affect community choice at the subnational level in a country where tax rate differences of several percentage points within a distance of $100 \mathrm{~km}$ are common, they are unlikely to have a large impact on international migration flows - that is, unless countries are offering huge tax rate discounts for immigrants only. The Netherlands and Sweden targeted their tax incentives towards 
highly skilled new arrivals, which might have had a positive fiscal impact, even if the overall impact on migration had been small.

\section{REFERENCES}

Acemoglu, D. 2002. “Technical Change, Inequality, and the Labour Market,” Journal of Economic Literature, $40,7-72$.

Brett, C., and J. Pinske. 2000. "The Determinants of Municipal Tax Rates in British Columbia," Canadian Journal of Economics, 33, 695-714.

Brueckner, J., and L. Saavedra. 2001. "Do Local Governments Engage in Strategic Property-Tax Competition?" National Tax Journal, 54, 203-229.

Bundesamt für Statistik. 2003. Eidgenössische Volkszählung 2000. Berne: Swiss Federal Statistical Office.

Cebula, R. J. 1979. “A Survey of the Migration-Impact of State and Local Government Policies,” Public Finance/Finances Publiques, 34, 69-84.

Clark, D. E., and W. J. Hunter. 1992. "The Impact of Economic Opportunity, Amenities, and Fiscal Factors on Age-Specific Migration Rates,”Journal of Regional Science, 21, 349-365.

Cremer, H., V. Fourgeaud, M. Leite-Monteiro, M. Marchand, and P. Pestieau. 1996. "Mobility and Redistribution: A Survey," Public Finance, 51, 325-352.

Dowding, K., and P. John. 1994. "Tiebout: A Survey of the Empirical Literature,” Urban Studies, 31, 767797.

Eidgenössische Steuerverwaltung. Various years. Steuerbelastung in der Schweiz. Natürliche Personen nach Gemeinden. Berne: Federal Tax Administration.

Feld, L. 2000. Steuerwettbewerb und seine Auswirkungen auf Allokation und Distribution: ein Überblick und eine Empirische Analyse für die Schweiz. Tübingen: Mohr Siebeck.

Feld, L., and G. Kirchgässner. 2001. "Income Tax Competition at the State and Local Level in Switzerland," Regional Science and Urban Economics, 31, 181-213. 
Fox, W. F., H. W. Herzog, and A. M. Schlottman. 1989. "Metropolitan Fiscal Structure and Migration," Journal of Regional Science, 29, 523-536.

Frey, R. 1981. "Bestimmungsfaktoren der inter- und Intraregionalen Wanderungen: Eine ökonometrische Untersuchung für die Schweiz und die Region Basel,” in R. Frey (ed.), Von der Land-zur Stadtflucht: Bestimmungsfaktoren der Bevölkerungswanderungen in der Region Basel. Bern: Peter Lang, pp. 13-52. Ghatak S., P. Levine, and S. Price. 1996. "Migration Theories and Evidence: An Assessment,” Journal of Economic Surveys, 10, 159-198.

Greenwood, M. J. 1985, “Human Migration: Theory, Models, and Empirical Studies, Journal of Regional Science, 25, 521-544.

Hansen, N., and A. Kessler. 2001. “(Non-)existence of Equilibria in Multicommunity Models," Journal of Urban Economics, 50, 418-435.

Iredale, R. 1999. “The Need to Import Skilled Personnel: Factors Favouring and Hindering its International Mobility," International Migration, 37, 89-123.

Joumard, I., and P. Konsgrud. 2003. Fiscal Relations across Government Levels, OECD Economics Department Working Paper No. 375, OECD, Paris.

Kirchgässner, G., and W. Pommerehne. 1996. "Tax Harmonization and Tax Competition in the European Union: Lessons from Switzerland,” Journal of Public Economics, 60, 351-371.

Knapp, T. A., and N. E. White. 1992. "Migration Decisions and Site-Specific Attributes of Public Policy: Microeconomic Evidence from the NLSY," Review of Regional Studies, 22, 169-184, Liebig, T. 2003. "Recruitment of Foreign Labour in Germany and Switzerland," in OECD (ed.), Migration for Employment: Bilateral Agreements at a Crossroads. Paris: OECD, pp. 157-186.

—. 2004. A New Phenomenon - The International Competition for Highly-Skilled Migrants and its Consequences for Germany. Stuttgart/Berne/Vienna: Haupt.

— , and A. Sousa-Poza. 2004. "Migration, Self-Selection and Income Inequality: An International Analysis," Kyklos, 57, 125-146. 
— _ and A. Sousa-Poza. 2006. "The Influence of Taxes on Migration: Evidence from Switzerland," Cambridge Journal of Economics, 30, 235-252.

Mahroum, S. 2001. "Europe and the Immigration of Highly-Skilled Labour," International Migration, 39, $27-43$

Massey, D., J. Arango, G. Hugo, A. Kouaouci, A. Pellegrino, and E. Taylor. 1993. “Theories of International Migration: A Review and Appraisal," Population and Development Review, 19, 431-466. Mieszowski, P., and G. Zodrow. 1989. "Taxation and the Tiebout Model: The Differential Effects of Head Taxes, Taxes on Land Rents, and Property Taxes," Journal of Economic Literature, 27, 1098-1146.

Oates, W. 1969. “The Effects of Property Taxes and Local Public Spending on Property Values: An Empirical Study of Tax Capitalisation and Tiebout Hypothesis," Journal of Political Economy, 77, 951971.

1972. Fiscal Federalism. New York: Harcourt Brace Jovanovich.

OECD. 1999a. Economic Surveys 1998-1999 Switzerland. Paris: OECD.

OECD. 1999b. Taxing Powers of State and Local Government, OECD Tax Policy Studies No. 1. Paris: OECD.

OECD. 2002. International Mobility of the Highly Skilled. Paris: OECD.

Razin, A., E. Sadka, and P. Swagel. 2002. "Tax Burden and Migration: A Political Economy Theory and Evidence," Journal of Public Economics, 85, 167-190.

Revelli, F. 2002. "Testing the Taxmimicking versus Expenditure Spill-over Hypotheses using English Data," Applied Economics, 34, 1723-1731.

Schmidheiny, K. 2006. "Income Segregation and Local Progressive Taxation: Empirical Evidence from Switzerland," Journal of Public Economics, 90, 429-458.

Schön, W., ed. 2003. Tax Competition in Europe. Amsterdam: International Bureau of Fiscal Documentation.

Sjaastad, L. 1962. “The Costs and Returns of Human Migration,” Journal of Political Economy, 70, 80-93. Stark, O. 1991. The Migration of Labor. Cambridge: Basil Blackwell. 
Tiebout, C. 1956. "A Pure Theory of Local Expenditures," Journal of Political Economy, 64, 416-424.

Waldburger, R. 2003. "National Report: Switzerland,” in W. Schön (ed.), Tax Competition in Europe. Amsterdam: International Bureau of Fiscal Documentation, pp. 471-478.

Wallace, S., and B. Edwards. 1999. "Personal Income Tax," in W. Hildreth and J. Richardson (eds.), Handbook on Taxation. New York and Basle: Dekker, pp. 149-190.

Walter-Busch, E. 1983. "Subjective and Objective Indicators of Regional Quality of Life in Switzerland," Social Indicators Research, 12, 337-391.

—. 1997. Regionale Lebensqualität in der Schweiz: Ergebnisse der Rekrutenbefragungen 1996, 1987 und 1978. Aarau: Sauerländer.

—. 2000. "Stability and Change of Regional Quality of Life in Switzerland, 1978-1996," Social Indicators Research, 50, 1-49.

Wilson, J. 1999. “Theories of Tax Competition,” National Tax Journal, 52, 269-304.

—. 2003. "The Property Tax: Competing Views and a Hybrid Theory," in S. Cnossen and H.-W. Sinn, (eds.), Public Finance and Public Policy in the New Century. Cambridge: MIT Press, pp. $217-235$. 


\section{TABLES}

TABLE 1: Summary Statistics by Nationality/Visa Group

\begin{tabular}{|c|c|c|c|}
\hline & Swiss citizens & $\begin{array}{l}\text { Permanent } \\
\text { residents } \\
\text { (C permit) }\end{array}$ & $\begin{array}{c}\text { Annual visa } \\
\text { holders } \\
\text { (B permit) }\end{array}$ \\
\hline Migration indicator & 0.088 & 0.061 & 0.111 \\
\hline \multirow[t]{2}{*}{ Level of average tax rate 1995} & 14.19 & 13.72 & 14.01 \\
\hline & $(3.56)$ & $(3.27)$ & $(3.35)$ \\
\hline \multirow[t]{2}{*}{ Change in average tax rate $1995-2000$} & -0.49 & -0.54 & -0.51 \\
\hline & $(0.55)$ & $(0.57)$ & $(0.54)$ \\
\hline Age $21-35$ & 0.30 & 0.31 & 0.53 \\
\hline Age $36-50$ & 0.39 & 0.42 & 0.42 \\
\hline Age 51-64 & 0.31 & 0.27 & 0.05 \\
\hline No vocational education & 0.14 & 0.46 & 0.51 \\
\hline Vocational education & 0.56 & 0.36 & 0.26 \\
\hline College degree & 0.30 & 0.18 & 0.23 \\
\hline Married in 1995 & 0.47 & 0.60 & 0.50 \\
\hline Male & 0.69 & 0.76 & 0.76 \\
\hline \multirow[t]{2}{*}{ Number of children in 1995} & 1.00 & 1.19 & 0.94 \\
\hline & $(1.20)$ & $(1.23)$ & $(1.27)$ \\
\hline \multirow[t]{2}{*}{ Quality of life index in 1995 community } & 2.22 & 2.27 & 2.26 \\
\hline & $(0.20)$ & $(0.20)$ & $(0.20)$ \\
\hline Agglomeration in 1995 & 0.81 & 0.87 & 0.82 \\
\hline \multirow[t]{2}{*}{ Number of inhabitants in 1995 community } & 43,352 & 55,698 & 62,342 \\
\hline & $(79,467)$ & $(87,822)$ & $(93,080)$ \\
\hline \multirow[t]{2}{*}{ Offered house price in 1995 community } & 4,058 & 4,068 & 4,118 \\
\hline & $(833)$ & $(823)$ & $(850)$ \\
\hline \multicolumn{4}{|l|}{ Community expenditures 1995 [000 CHF] } \\
\hline \multirow[t]{2}{*}{ Administration } & 61,806 & 70,872 & 79,242 \\
\hline & $(88,647)$ & $(91,661)$ & $(95,376)$ \\
\hline \multirow[t]{2}{*}{ Law and order } & 77,181 & 85,379 & 100,187 \\
\hline & $(120,789)$ & $(124,226)$ & $(132,095)$ \\
\hline \multirow[t]{2}{*}{ Education } & 143,214 & 151,955 & 181,353 \\
\hline & $(203,595)$ & $(211,297)$ & $(230,825)$ \\
\hline \multirow[t]{2}{*}{ Culture } & 62,644 & 75,687 & 82,454 \\
\hline & $(82,171)$ & $(87,303)$ & $(89,010)$ \\
\hline \multirow[t]{2}{*}{ Health } & 124,140 & 136,976 & 169,637 \\
\hline & $(244,828)$ & $(256,309)$ & $(283,182)$ \\
\hline \multirow[t]{2}{*}{ Social welfare } & 173,723 & 188,702 & 219,455 \\
\hline & $(291,542)$ & $(303,154)$ & $(319,265)$ \\
\hline \multirow[t]{2}{*}{ Transport } & 61,888 & 68,597 & 79,586 \\
\hline & $(88,527)$ & $(91,210)$ & $(95,796)$ \\
\hline \multirow[t]{2}{*}{ Environment } & 49,154 & 54,750 & 61,109 \\
\hline & $(71,240)$ & $(73,596)$ & $(76,864)$ \\
\hline \multirow[t]{2}{*}{ Other } & 102,820 & 116,287 & 130,719 \\
\hline & $(152,684)$ & $(156,812)$ & $(164,062)$ \\
\hline
\end{tabular}


TABLE 1: Summary Statistics by Nationality/Visa Group (ctd.)

\begin{tabular}{lccc}
\hline & Swiss citizens & $\begin{array}{c}\text { Permanent } \\
\text { residents } \\
\text { (C permit) }\end{array}$ & $\begin{array}{c}\text { Annual visa } \\
\text { holders } \\
\text { (B permit) }\end{array}$ \\
\hline Difference in community expenditures 2000-1995 & C000 CHF] & & \\
Administration & $-1,881$ & $-1,585$ & $-1,219$ \\
Law and order & $(24,686)$ & $(26,198)$ & $(29,323)$ \\
& 2,228 & 2,563 & 2,629 \\
Education & $(10,467)$ & $(10,670)$ & $(11,409)$ \\
& 5,892 & 6,591 & 9,473 \\
Culture & $(26,059)$ & $(26,599)$ & $(29,670)$ \\
& 3,157 & 4,467 & 4,202 \\
Health & $(12,130)$ & $(13,503)$ & $(14,356)$ \\
Social welfare & 1,802 & 1,667 & 649 \\
Transport & $(24,753)$ & $(26,242)$ & $(29,850)$ \\
& 22,908 & 24,263 & 28,607 \\
Environment & $(32,347)$ & $(33,511)$ & $(36,694)$ \\
Other & 989 & 1,501 & 3,231 \\
& $(33,000)$ & $(34,915)$ & $(39,855)$ \\
Number of observations & 718 & 822 & 769 \\
Number of observations (expenditure data) & $(7,497)$ & $(7,423)$ & $(7,863)$ \\
\hline
\end{tabular}

Notes: Standard errors are only provided for nonbinary variables. The Walter-Busch (1997) quality of life index is measured on a scale from 1 to 5. Wüest and Partner's offered house prices are measured in CHF per square meter.

Sources: Swiss Census 2000; community-level statistics on average tax rates, quality of life, house prices, and community expenditures (as described in the Data section of this paper); authors' own calculations. 
TABLE 2: Ten Most Important Countries of Origin for Foreigners with Permanent Residency (C Permit) or Annual Visa (B

Permit) in Switzerland

\begin{tabular}{|c|c|c|c|c|}
\hline \multirow[b]{2}{*}{$\begin{array}{c}\text { Rank } \\
\text { according } \\
\text { to share }\end{array}$} & \multicolumn{2}{|c|}{ Permanent residency (C permit) } & \multicolumn{2}{|c|}{ Annual visa (B permit) } \\
\hline & $\begin{array}{c}\text { Country of } \\
\text { origin }\end{array}$ & $\begin{array}{c}\text { Share } \\
\text { (share of college } \\
\text { graduates) }\end{array}$ & $\begin{array}{c}\text { Country of } \\
\text { origin }\end{array}$ & $\begin{array}{c}\text { Share } \\
\text { (share of college } \\
\text { graduates) }\end{array}$ \\
\hline 1. & Italy & $\begin{array}{c}32.8 \\
(10.3)\end{array}$ & $\begin{array}{l}\text { Serbia and } \\
\text { Montenegro }\end{array}$ & $\begin{array}{c}24.2 \\
(11.1)\end{array}$ \\
\hline 2. & Portugal & $\begin{array}{l}9.6 \\
(2.3)\end{array}$ & Sri Lanka & $\begin{array}{c}9.7 \\
(3.8)\end{array}$ \\
\hline 3. & Germany & $\begin{array}{c}9.5 \\
(47.6)\end{array}$ & $\begin{array}{l}\text { Bosnia and } \\
\text { Herzegovina }\end{array}$ & $\begin{array}{c}7.2 \\
(13.1)\end{array}$ \\
\hline 4. & Spain & $\begin{array}{l}9.0 \\
(8.5)\end{array}$ & Turkey & $\begin{array}{c}6.9 \\
(4.6)\end{array}$ \\
\hline 5. & $\begin{array}{c}\text { Serbia and } \\
\text { Montenegro }\end{array}$ & $\begin{array}{c}8.1 \\
(7.9)\end{array}$ & $\begin{array}{c}\text { FYR } \\
\text { Macedonia }\end{array}$ & $\begin{array}{c}6.8 \\
(8.6)\end{array}$ \\
\hline 6. & Turkey & $\begin{array}{c}4.7 \\
(6.5)\end{array}$ & Croatia & $\begin{array}{c}6.6 \\
(15.9)\end{array}$ \\
\hline 7. & France & $\begin{array}{c}4.6 \\
(37.4)\end{array}$ & Germany & $\begin{array}{c}5.0 \\
(76.0)\end{array}$ \\
\hline 8. & Austria & $\begin{array}{c}3.3 \\
(30.0)\end{array}$ & Portugal & $\begin{array}{l}4.8 \\
(3.4)\end{array}$ \\
\hline 9. & Croatia & $\begin{array}{c}2.8 \\
(9.5)\end{array}$ & Italy & $\begin{array}{c}3.2 \\
(24.2)\end{array}$ \\
\hline 10. & $\begin{array}{l}\text { Bosnia and } \\
\text { Herzegovina }\end{array}$ & $\begin{array}{c}2.2 \\
(6.8)\end{array}$ & France & $\begin{array}{c}2.3 \\
(49.6)\end{array}$ \\
\hline
\end{tabular}

Notes: The percentages in parentheses indicate the share of college graduates within the visa/nationality group. The numbers in this table are calculated for household heads in the estimation sample reported in Table 5. College graduates are divided into the following German-language categories: Höhere Fach- und Berufsausbildung, Höhere Fachschule, Fachhochschule, and Universität/Hochschule.

Sources: Swiss Census 2000; authors' own calculations. 
TABLE 3: The Association Between Community Tax Rates and Internal Migration

A. Swiss citizens

\begin{tabular}{|c|c|c|c|c|c|c|}
\hline & $\begin{array}{c}(1) \\
\text { No controls } \\
\end{array}$ & $\begin{array}{c}(2) \\
\text { Household } \\
\text { characteristics }\end{array}$ & $\begin{array}{c}\text { (3) } \\
\text { Quality of life } \\
\end{array}$ & $\begin{array}{c}(4) \\
\text { House prices }\end{array}$ & $\begin{array}{c}(5) \\
\text { House prices } \\
\text { expenditure } \\
\text { sample } \\
\end{array}$ & $\begin{array}{c}\text { (6) } \\
\text { Community } \\
\text { expenditure } \\
\end{array}$ \\
\hline No voc. age $21-35$ & -0.002 & -0.002 & -0.001 & $-0.010 * *$ & $-0.016^{* *}$ & $-0.006 * *$ \\
\hline (s.e.) & $(0.002)$ & $(0.002)$ & $(0.002)$ & $(0.002)$ & $(0.002)$ & $(0.002)$ \\
\hline No voc. age $36-50$ & $0.007 * *$ & $0.007 * *$ & $0.006^{* *}$ & $0.006 * *$ & $0.004 * *$ & 0.000 \\
\hline (s.e.) & $(0.001)$ & $(0.001)$ & $(0.001)$ & $(0.001)$ & $(0.001)$ & $(0.001)$ \\
\hline No voc. age $51-64$ & $-0.004 * *$ & $-0.004 * *$ & $-0.005 * *$ & $-0.002 * *$ & 0.000 & $-0.003 * *$ \\
\hline (s.e.) & $(0.001)$ & $(0.001)$ & $(0.001)$ & $(0.001)$ & $(0.001)$ & $(0.001)$ \\
\hline Voc. qual. age $21-35$ & $0.016^{* *}$ & $0.015^{* *}$ & $0.015^{* *}$ & $0.006^{* *}$ & $0.003 * *$ & $0.012 * *$ \\
\hline (s.e.) & $(0.001)$ & $(0.001)$ & $(0.001)$ & $(0.001)$ & $(0.001)$ & $(0.001)$ \\
\hline Voc. qual. age $36-50$ & $0.012 * *$ & $0.010 * *$ & $0.009 * *$ & $0.009 * *$ & $0.008 * *$ & $0.005 * *$ \\
\hline (s.e.) & $(0.000)$ & $(0.000)$ & $(0.000)$ & $(0.000)$ & $(0.000)$ & $(0.001)$ \\
\hline Voc. qual. age 51-64 & $0.003 * *$ & $0.003 * *$ & $-0.001 *$ & $0.002 * *$ & $0.002 * *$ & $0.001 * *$ \\
\hline (s.e.) & $(0.000)$ & $(0.000)$ & $(0.000)$ & $(0.000)$ & $(0.000)$ & $(0.000)$ \\
\hline College age $21-35$ & $0.037 * *$ & $0.035^{* *}$ & $0.034 * *$ & $0.024 * *$ & $0.025^{* *}$ & $0.028 * *$ \\
\hline (s.e.) & $(0.001)$ & $(0.001)$ & $(0.001)$ & $(0.001)$ & $(0.001)$ & $(0.001)$ \\
\hline College age $36-50$ & $0.016^{* *}$ & $0.013 * *$ & $0.012 * *$ & $0.011 * *$ & $0.010 * *$ & $0.009 * *$ \\
\hline (s.e.) & $(0.000)$ & $(0.000)$ & $(0.000)$ & $(0.000)$ & $(0.001)$ & $(0.001)$ \\
\hline College age $51-64$ & $0.006^{* *}$ & $0.005 * *$ & $0.004 * *$ & $0.005 * *$ & $0.001 *$ & $0.002 * *$ \\
\hline (s.e.) & $(0.000)$ & $(0.000)$ & $(0.000)$ & $(0.000)$ & $(0.001)$ & $(0.001)$ \\
\hline
\end{tabular}

B. Permanent residents ( $\mathrm{C}$ permit)

\begin{tabular}{|c|c|c|c|c|c|c|}
\hline & $\begin{array}{c}(1) \\
\text { No controls }\end{array}$ & $\begin{array}{c}(2) \\
\text { Household } \\
\text { characteristics } \\
\end{array}$ & $\begin{array}{c}\text { (3) } \\
\text { Quality of life }\end{array}$ & $\begin{array}{c}(4) \\
\text { House prices }\end{array}$ & $\begin{array}{c}(5) \\
\text { House prices } \\
\text { expenditure } \\
\text { sample }\end{array}$ & $\begin{array}{c}(6) \\
\text { Community } \\
\text { expenditure }\end{array}$ \\
\hline No voc. age $21-35$ & $0.017 * *$ & $0.015^{* *}$ & $0.016^{* *}$ & $0.010 * *$ & $0.004 * *$ & $0.003 *$ \\
\hline (s.e.) & $(0.001)$ & $(0.001)$ & $(0.001)$ & $(0.001)$ & $(0.002)$ & $(0.002)$ \\
\hline No voc. age $36-50$ & $0.008^{* *}$ & $0.007 * *$ & $0.007 * *$ & $0.004 * *$ & $0.002 *$ & 0.000 \\
\hline (s.e.) & $(0.001)$ & $(0.001)$ & $(0.001)$ & $(0.001)$ & $(0.001)$ & $(0.001)$ \\
\hline No voc. age $51-64$ & $0.002 * *$ & $0.002 * *$ & $0.002 * *$ & $0.001 * *$ & $0.003 * *$ & $0.002 * *$ \\
\hline (s.e.) & $(0.001)$ & $(0.001)$ & $(0.001)$ & $(0.001)$ & $(0.000)$ & $(0.001)$ \\
\hline Voc. qual. age $21-35$ & $0.021 * *$ & $0.010 * *$ & $0.009 * *$ & $0.010 * *$ & $0.008 * *$ & 0.002 \\
\hline (s.e.) & $(0.001)$ & $(0.001)$ & $(0.001)$ & $(0.001)$ & $(0.001)$ & $(0.002)$ \\
\hline Voc. qual. age $36-50$ & $0.015 * *$ & $0.013^{* *}$ & $0.013 * *$ & $0.012 * *$ & $0.009 * *$ & $0.006^{* *}$ \\
\hline (s.e.) & $(0.001)$ & $(0.001)$ & $(0.001)$ & $(0.001)$ & $(0.001)$ & $(0.001)$ \\
\hline Voc. qual. age 51-64 & $0.005 * *$ & $0.004 * *$ & $0.003 * *$ & $0.004 * *$ & $0.004 * *$ & $0.004 * *$ \\
\hline (s.e.) & $(0.001)$ & $(0.001)$ & $(0.001)$ & $(0.001)$ & $(0.001)$ & $(0.001)$ \\
\hline College age $21-35$ & $0.030 * *$ & $0.029 * *$ & $0.030 * *$ & $0.015^{* *}$ & $0.019 * *$ & $0.016^{* *}$ \\
\hline (s.e.) & $(0.002)$ & $(0.002)$ & $(0.002)$ & $(0.002)$ & $(0.003)$ & $(0.003)$ \\
\hline College age $36-50$ & $0.020 * *$ & $0.018^{* *}$ & $0.019 * *$ & $0.011^{* *}$ & $0.010^{* *}$ & $0.008^{* *}$ \\
\hline (s.e.) & $(0.001)$ & $(0.001)$ & $(0.001)$ & $(0.001)$ & $(0.002)$ & $(0.002)$ \\
\hline College age 51-64 & $0.005^{* *}$ & $0.005^{* *}$ & $0.005^{* *}$ & $0.004 * *$ & 0.001 & $0.003^{* *}$ \\
\hline (s.e.) & $(0.001)$ & $(0.001)$ & $(0.001)$ & $(0.001)$ & $(0.002)$ & $(0.001)$ \\
\hline
\end{tabular}


C. Annual visa holders (B permit)

\begin{tabular}{|c|c|c|c|c|c|c|}
\hline & $\begin{array}{c}(1) \\
\text { No controls }\end{array}$ & $\begin{array}{c}(2) \\
\text { Household } \\
\text { characteristics }\end{array}$ & $\begin{array}{c}\text { (3) } \\
\text { Quality of life }\end{array}$ & $\begin{array}{c}(4) \\
\text { House prices }\end{array}$ & $\begin{array}{c}(5) \\
\text { House prices } \\
\text { expenditure } \\
\text { sample }\end{array}$ & $\begin{array}{c}\text { (6) } \\
\text { Community } \\
\text { expenditure }\end{array}$ \\
\hline No voc. age $21-35$ & $0.016^{* *}$ & $0.014 * *$ & $0.016 * *$ & $0.014^{* *}$ & $0.010 * *$ & $0.011 * *$ \\
\hline (s.e.) & $(0.003)$ & $(0.003)$ & $(0.002)$ & $(0.003)$ & $(0.003)$ & $(0.003)$ \\
\hline No voc. age $36-50$ & $0.017 * *$ & $0.016^{* *}$ & $0.014 * *$ & $0.012 * *$ & $0.009 * *$ & 0.004 \\
\hline (s.e.) & $(0.002)$ & $(0.002)$ & $(0.002)$ & $(0.002)$ & $(0.002)$ & $(0.002)$ \\
\hline No voc. age $51-64$ & -0.004 & -0.002 & -0.004 & -0.009 & 0.002 & 0.000 \\
\hline (s.e.) & $(0.008)$ & $(0.006)$ & $(0.003)$ & $(0.003)$ & $(0.003)$ & $(0.000)$ \\
\hline Voc. qual. age $21-35$ & $0.012 * *$ & $0.018^{* *}$ & $0.018^{* *}$ & $0.007 *$ & -0.001 & 0.001 \\
\hline (s.e.) & $(0.004)$ & $(0.004)$ & $(0.003)$ & $(0.004)$ & $(0.004)$ & $(0.004)$ \\
\hline Voc. qual. age $36-50$ & $0.022 * *$ & $0.018^{* *}$ & $0.018^{* *}$ & $0.017 * *$ & $0.019 * *$ & $0.013^{* *}$ \\
\hline (s.e.) & $(0.003)$ & $(0.003)$ & $(0.003)$ & $(0.003)$ & $(0.003)$ & $(0.003)$ \\
\hline Voc. qual. age 51-64 & $0.020 * *$ & $0.017^{*}$ & 0.012 & $0.023^{* *}$ & 0.002 & 0.000 \\
\hline (s.e.) & $(0.010)$ & $(0.010)$ & $(0.010)$ & $(0.009)$ & $(0.004)$ & $(0.000)$ \\
\hline College age $21-35$ & $0.033^{* *}$ & $0.030 * *$ & $0.026^{* *}$ & 0.006 & $0.014 * *$ & $0.021 * *$ \\
\hline (s.e.) & $(0.004)$ & $(0.004)$ & $(0.004)$ & $(0.005)$ & $(0.006)$ & $(0.007)$ \\
\hline College age $36-50$ & $0.016^{* *}$ & $0.013^{* *}$ & $0.014 * *$ & 0.003 & $-0.009^{*}$ & $-0.019 * *$ \\
\hline (s.e.) & $(0.004)$ & $(0.003)$ & $(0.004)$ & $(0.004)$ & $(0.005)$ & $(0.006)$ \\
\hline College age 51-64 & $0.021 * *$ & $0.019 * *$ & $0.018^{* *}$ & -0.006 & 0.001 & -0.005 \\
\hline (s.e.) & $(0.006)$ & $(0.006)$ & $(0.006)$ & $(0.006)$ & $(0.008)$ & $(0.007)$ \\
\hline
\end{tabular}

Notes: ** $(*)$ indicates statistical significance at the 5 percent $(10$ percent) level. Reported estimates refer to the effect at the sample mean of a marginal change in tax rate (between the 1995 and 2000 communities of residence) on the probability of migration. Estimates are obtained from logit regressions. Displayed standard errors for the marginal effects are calculated using the delta method. In column (2), the control variables are age, gender, marital status, and number of children in 1995. In column (3), we additionally control for the 1996 Walter-Busch (1997) quality of life index in the 1995 community of residence minus the 1996 quality of life index in the 2000 community of residence. We also add in the difference in number of inhabitants for the 1995 and 2000 communities of residence. In column (4), we add Wüest and Partner's offered house prices for the year 2000 in the 1995 community of residence minus these same offered house prices in the 2000 community of residence. In column (5), we estimate the same regression as in column (4) but using the restricted sample for which community expenditure data are available. In column (6), we add in the difference in 1995 and 2000 community expenditures for the respective 1995 and 2000 communities of residence. We include nine different expenditure variables, referring to general administration, law and order, education, culture, health, social welfare, transport, environment, and other expenditures.

Sample sizes per subgroup range from 30,607 to 257,881 (expenditure sample: 15,537 to 124,495) for Swiss citizens (Panel A); 11,236 to 55,961 (expenditure sample: 6,552 to 34,074) for permanent residents (Panel B); and 374 to 9,452 (expenditure sample: 219 to 5,530) for annual visa holders (Panel C).

Sources: Swiss Census 2000; community-level statistics on average tax rates, quality of life, house prices, and community expenditures (as described in the Data section of this paper); authors' own calculations. 
TABLE 4: Level of 1995 Community Tax Rates and Internal Migration

A. Swiss citizens

\begin{tabular}{|c|c|c|c|c|c|c|}
\hline & $\begin{array}{c}\text { (1) } \\
\text { Earnings } \\
\text { interval } \\
\end{array}$ & $\begin{array}{c}(2) \\
\text { Household } \\
\text { characteristics }\end{array}$ & $\begin{array}{c}\text { (3) } \\
\text { Quality of life }\end{array}$ & $\begin{array}{c}(4) \\
\text { House prices } \\
\end{array}$ & $\begin{array}{c}(5) \\
\text { House prices } \\
\text { expenditure } \\
\text { sample }\end{array}$ & $\begin{array}{c}(6) \\
\text { Community } \\
\text { expenditure }\end{array}$ \\
\hline No voc. age $21-35$ & $-0.005 * *$ & $-0.005 * *$ & $-0.005 * *$ & $-0.005^{* *}$ & -0.001 & -0.0028 \\
\hline (s.e.) & $(0.001)$ & $(0.001)$ & $(0.001)$ & $(0.001)$ & $(0.001)$ & $(0.002)$ \\
\hline No voc. age $36-50$ & $-0.002 * *$ & $-0.002 * *$ & $-0.002 * *$ & $-0.001 * *$ & $0.001^{*}$ & -0.001 \\
\hline (s.e.) & $(0.000)$ & $(0.000)$ & $(0.000)$ & $(0.000)$ & $(0.001)$ & $(0.001)$ \\
\hline No voc. age 51-64 & $-0.002 * *$ & $-0.002 * *$ & $-0.001 * *$ & 0.000 & 0.001 & $-0.002 * *$ \\
\hline (s.e.) & $(0.000)$ & $(0.000)$ & $(0.000)$ & $(0.000)$ & $(0.000)$ & $(0.001)$ \\
\hline Voc. qual. age 21-35 & -0.001 & 0.000 & 0.000 & 0.000 & $0.007 * *$ & 0.000 \\
\hline (s.e.) & $(0.000)$ & $(0.000)$ & $(0.000)$ & $(0.000)$ & $(0.001)$ & $(0.001)$ \\
\hline Voc. qual. age $36-50$ & $-0.002 * *$ & $-0.001 * *$ & $-0.001 * *$ & 0.000 & $0.003 * *$ & $-0.001 * *$ \\
\hline (s.e.) & $(0.000)$ & $(0.000)$ & $(0.000)$ & $(0.000)$ & $(0.000)$ & $(0.000)$ \\
\hline Voc. qual. age 51-64 & -0.001 & -0.001 & -0.001 & 0.000 & 0.001 & -0.001 \\
\hline (s.e.) & $(0.000)$ & $(0.000)$ & $(0.000)$ & $(0.000)$ & $(0.000)$ & $(0.000)$ \\
\hline College age $21-35$ & $0.006^{* *}$ & $0.004 * *$ & $0.004 * *$ & $0.001 * *$ & $0.009 * *$ & $0.007 * *$ \\
\hline (s.e.) & $(0.001)$ & $(0.001)$ & $(0.001)$ & $(0.001)$ & $(0.001)$ & $(0.001)$ \\
\hline College age $36-50$ & $-0.001 * *$ & 0.000 & 0.000 & 0.000 & $0.003 * *$ & $-0.001 * *$ \\
\hline (s.e.) & $(0.000)$ & $(0.000)$ & $(0.000)$ & $(0.000)$ & $(0.000)$ & $(0.001)$ \\
\hline College age $51-64$ & $-0.001 * *$ & $-0.001 * *$ & $-0.001 * *$ & $-0.001 * *$ & 0.001 & 0.000 \\
\hline (s.e.) & $(0.000)$ & $(0.000)$ & $(0.000)$ & $(0.000)$ & $(0.000)$ & $(0.001)$ \\
\hline
\end{tabular}

B. Permanent residents ( $\mathrm{C}$ permit $)$

\begin{tabular}{|c|c|c|c|c|c|c|}
\hline & $\begin{array}{l}\text { (1) } \\
\text { Earnings } \\
\text { interval }\end{array}$ & $\begin{array}{c}(2) \\
\text { Household } \\
\text { characteristics }\end{array}$ & $\begin{array}{c}\text { (3) } \\
\text { Quality of life }\end{array}$ & $\begin{array}{c}\text { (4) } \\
\text { House prices }\end{array}$ & $\begin{array}{l}(5) \\
\text { House prices } \\
\text { expenditure } \\
\text { sample }\end{array}$ & $\begin{array}{c}\text { (6) } \\
\text { Community } \\
\text { expenditure }\end{array}$ \\
\hline $\begin{array}{l}\text { No voc. age } 21-35 \\
\text { (s.e.) }\end{array}$ & $\begin{array}{c}-0.003 * * \\
(0.001)\end{array}$ & $\begin{array}{c}-0.003 * * \\
(0.001)\end{array}$ & $\begin{array}{c}-0.003 * * \\
(0.001)\end{array}$ & $\begin{array}{c}-0.002 * * \\
(0.001)\end{array}$ & $\begin{array}{c}0.001 \\
(0.001)\end{array}$ & $\begin{array}{c}0.000 \\
(0.001)\end{array}$ \\
\hline $\begin{array}{l}\text { No voc. age } 36-50 \\
\text { (s.e.) }\end{array}$ & $\begin{array}{c}-0.001 * * \\
(0.000)\end{array}$ & $\begin{array}{c}-0.001 * * \\
(0.000)\end{array}$ & $\begin{array}{c}-0.001 * * \\
(0.000)\end{array}$ & $\begin{array}{c}-0.001 * * \\
(0.000)\end{array}$ & $\begin{array}{c}0.000 \\
(0.000)\end{array}$ & $\begin{array}{l}-0.001 \\
(0.000)\end{array}$ \\
\hline $\begin{array}{l}\text { No voc. age } 51-64 \\
\text { (s.e.) }\end{array}$ & $\begin{array}{c}-0.001 * * \\
(0.000)\end{array}$ & $\begin{array}{c}-0.001 * * \\
(0.000)\end{array}$ & $\begin{array}{c}-0.001 * * \\
(0.000)\end{array}$ & $\begin{array}{c}0.000 \\
(0.000) \\
\end{array}$ & $\begin{array}{c}0.000 \\
(0.000)\end{array}$ & $\begin{array}{l}-0.001 \\
(0.000) \\
\end{array}$ \\
\hline $\begin{array}{l}\text { Voc. qual. age } 21-35 \\
\text { (s.e.) }\end{array}$ & $\begin{array}{c}-0.002 * * \\
(0.001)\end{array}$ & $\begin{array}{l}-0.001 * \\
(0.001)\end{array}$ & $\begin{array}{l}-0.001 * \\
(0.001)\end{array}$ & $\begin{array}{c}-0.002 * * \\
(0.001)\end{array}$ & $\begin{array}{l}0.003 * * \\
(0.001)\end{array}$ & $\begin{array}{l}-0.001 \\
(0.001)\end{array}$ \\
\hline $\begin{array}{l}\text { Voc. qual. age } 36-50 \\
\text { (s.e.) }\end{array}$ & $\begin{array}{c}-0.002 * * \\
(0.001)\end{array}$ & $\begin{array}{c}-0.002 * * \\
(0.000)\end{array}$ & $\begin{array}{c}-0.002 * * \\
(0.000)\end{array}$ & $\begin{array}{c}0.000 \\
(0.001)\end{array}$ & $\begin{array}{l}0.002 * * \\
(0.001)\end{array}$ & $\begin{array}{c}0.000 \\
(0.001)\end{array}$ \\
\hline $\begin{array}{l}\text { Voc. qual. age } 51-64 \\
\text { (s.e.) }\end{array}$ & $\begin{array}{c}-0.002 * * \\
(0.000)\end{array}$ & $\begin{array}{c}-0.002 * * \\
(0.000)\end{array}$ & $\begin{array}{c}-0.002 * * \\
(0.000)\end{array}$ & $\begin{array}{c}-0.001 * * \\
(0.000)\end{array}$ & $\begin{array}{c}0.000 \\
(0.001)\end{array}$ & $\begin{array}{l}-0.001 \\
(0.001)\end{array}$ \\
\hline $\begin{array}{l}\text { College age } 21-35 \\
\text { (s.e.) }\end{array}$ & $\begin{array}{l}-0.002 \\
(0.001)\end{array}$ & $\begin{array}{l}-0.002 \\
(0.001)\end{array}$ & $\begin{array}{l}-0.001 \\
(0.001)\end{array}$ & $\begin{array}{l}-0.005 * * \\
(0.002)\end{array}$ & $\begin{array}{c}0.000 \\
(0.002)\end{array}$ & $\begin{array}{l}-0.002 \\
(0.003)\end{array}$ \\
\hline $\begin{array}{l}\text { College age } 36-50 \\
\text { (s.e.) }\end{array}$ & $\begin{array}{l}-0.001 \\
(0.001)\end{array}$ & $\begin{array}{l}-0.001 \\
(0.001)\end{array}$ & $\begin{array}{l}-0.001 \\
(0.001)\end{array}$ & $\begin{array}{c}-0.002 * * \\
(0.001)\end{array}$ & $\begin{array}{c}0.001 \\
(0.001)\end{array}$ & $\begin{array}{l}-0.002 \\
(0.002)\end{array}$ \\
\hline $\begin{array}{l}\text { College age } 51-64 \\
\text { (s.e.) }\end{array}$ & $\begin{array}{c}-0.002 * * \\
(0.001)\end{array}$ & $\begin{array}{c}-0.002 * * \\
(0.001)\end{array}$ & $\begin{array}{c}-0.002 * * \\
(0.001)\end{array}$ & $\begin{array}{l}-0.001 \\
(0.001)\end{array}$ & $\begin{array}{c}0.000 \\
(0.001)\end{array}$ & $\begin{array}{c}0.001 \\
(0.002) \\
\end{array}$ \\
\hline
\end{tabular}


C. Annual visa holders (B permit)

\begin{tabular}{|c|c|c|c|c|c|c|}
\hline & $\begin{array}{c}\text { (1) } \\
\text { Earnings } \\
\text { interval }\end{array}$ & $\begin{array}{c}(2) \\
\text { Household } \\
\text { characteristics }\end{array}$ & $\begin{array}{c}\text { (3) } \\
\text { Quality of life }\end{array}$ & $\begin{array}{c}(4) \\
\text { House prices }\end{array}$ & $\begin{array}{c}(5) \\
\text { House prices } \\
\text { expenditure } \\
\text { sample }\end{array}$ & $\begin{array}{c}(6) \\
\text { Community } \\
\text { expenditure }\end{array}$ \\
\hline $\begin{array}{l}\text { No voc. age } 21-35 \\
\text { (s.e.) }\end{array}$ & $\begin{array}{c}-0.003 * * \\
(0.001)\end{array}$ & $\begin{array}{c}-0.003 * * \\
(0.001)\end{array}$ & $\begin{array}{c}-0.003 * * \\
(0.001)\end{array}$ & $\begin{array}{l}-0.002 \\
(0.002)\end{array}$ & $\begin{array}{c}0.000 \\
(0.002)\end{array}$ & $\begin{array}{l}-0.001 \\
(0.003)\end{array}$ \\
\hline $\begin{array}{l}\text { No voc. age } 36-50 \\
\text { (s.e.) }\end{array}$ & $\begin{array}{c}-0.003 * * \\
(0.001)\end{array}$ & $\begin{array}{c}-0.003 * * \\
(0.001)\end{array}$ & $\begin{array}{c}-0.003 * * \\
(0.001)\end{array}$ & $\begin{array}{l}-0.001 \\
(0.001)\end{array}$ & $\begin{array}{c}0.001 \\
(0.001)\end{array}$ & $\begin{array}{l}-0.003 \\
(0.002)\end{array}$ \\
\hline $\begin{array}{l}\text { No voc. age } 51-64 \\
\text { (s.e.) }\end{array}$ & $\begin{array}{c}-0.005 * * \\
(0.002)\end{array}$ & $\begin{array}{c}-0.004 * * \\
(0.002)\end{array}$ & $\begin{array}{l}-0.003 * \\
(0.002) \\
\end{array}$ & $\begin{array}{c}-0.004 * * \\
(0.002)\end{array}$ & $\begin{array}{c}0.000 \\
(0.001) \\
\end{array}$ & $\begin{array}{c}0.000 \\
(0.001) \\
\end{array}$ \\
\hline $\begin{array}{l}\text { Voc. qual. age } 21-35 \\
\text { (s.e.) }\end{array}$ & $\begin{array}{l}-0.004 * \\
(0.002)\end{array}$ & $\begin{array}{c}0.000 \\
(0.002)\end{array}$ & $\begin{array}{c}0.000 \\
(0.002)\end{array}$ & $\begin{array}{l}-0.003 \\
(0.002)\end{array}$ & $\begin{array}{c}0.000 \\
(0.003)\end{array}$ & $\begin{array}{c}0.003 \\
(0.004)\end{array}$ \\
\hline $\begin{array}{l}\text { Voc. qual. age } 36-50 \\
\text { (s.e.) }\end{array}$ & $\begin{array}{c}0.001 \\
(0.002)\end{array}$ & $\begin{array}{c}0.000 \\
(0.002)\end{array}$ & $\begin{array}{c}0.000 \\
(0.002)\end{array}$ & $\begin{array}{c}0.002 \\
(0.002)\end{array}$ & $\begin{array}{c}0.002 \\
(0.002)\end{array}$ & $\begin{array}{c}0.001 \\
(0.003)\end{array}$ \\
\hline $\begin{array}{l}\text { Voc. qual. age } 51-64 \\
\text { (s.e.) }\end{array}$ & $\begin{array}{l}-0.007 \\
(0.005) \\
\end{array}$ & $\begin{array}{l}-0.006 \\
(0.004) \\
\end{array}$ & $\begin{array}{l}-0.007 \\
(0.005) \\
\end{array}$ & $\begin{array}{l}-0.006 \\
(0.005)\end{array}$ & $\begin{array}{l}-0.008 \\
(0.006) \\
\end{array}$ & $\begin{array}{l}-0.008 \\
(0.007) \\
\end{array}$ \\
\hline $\begin{array}{l}\text { College age } 21-35 \\
\text { (s.e.) }\end{array}$ & $\begin{array}{c}0.002 \\
(0.003)\end{array}$ & $\begin{array}{c}0.001 \\
(0.003)\end{array}$ & $\begin{array}{l}-0.003 \\
(0.003)\end{array}$ & $\begin{array}{c}-0.010 * * \\
(0.004)\end{array}$ & $\begin{array}{l}-0.006 \\
(0.004)\end{array}$ & $\begin{array}{l}-0.003 \\
(0.007)\end{array}$ \\
\hline $\begin{array}{l}\text { College age } 36-50 \\
\text { (s.e.) }\end{array}$ & $\begin{array}{l}-0.001 \\
(0.002)\end{array}$ & $\begin{array}{l}-0.002 \\
(0.002)\end{array}$ & $\begin{array}{l}-0.001 \\
(0.002)\end{array}$ & $\begin{array}{l}-0.003 \\
(0.003)\end{array}$ & $\begin{array}{l}-0.001 \\
(0.003)\end{array}$ & $\begin{array}{l}-0.009 \\
(0.005)\end{array}$ \\
\hline $\begin{array}{l}\text { College age 51-64 } \\
\text { (s.e.) }\end{array}$ & $\begin{array}{l}-0.004 \\
(0.004)\end{array}$ & $\begin{array}{l}-0.004 \\
(0.004)\end{array}$ & $\begin{array}{l}-0.004 \\
(0.004)\end{array}$ & $\begin{array}{l}-0.006 \\
(0.005)\end{array}$ & $\begin{array}{c}0.004 \\
(0.006)\end{array}$ & $\begin{array}{c}0.007 \\
(0.010)\end{array}$ \\
\hline
\end{tabular}

Notes: ** $(*)$ indicates statistical significance at the 5 percent $(10$ percent) level. Reported estimates refer to the effect at the sample mean of a marginal increase in the 1995 tax rate in the 1995 community of residence on the probability of migration. Estimates are obtained from logit regressions. Displayed standard errors for the marginal effects are calculated using the delta method. In column (1), we control for predicted earnings using dummy variables for any of eleven earnings intervals. In column (2), the additional control variables are age, gender, marital status, and number of children in 1995. In column (3), we additionally control for the 1996 Walter-Busch (1997) quality of life index in the 1995 community of residence. We also add in the number of inhabitants in the 1995 community of residence and an agglomeration indicator provided by the Federal Statistical Office (2003). In column (4), we add in Wüest and Partner's offered house prices for the year 2000 in the 1995 community of residence. In column (5), we estimate the same regression as in column (4) but using the restricted sample for which community expenditure data are available. In column (6), we add in the 1995 community expenditures for the 1995 community of residence. We include nine different expenditure variables, referring to general administration, law and order, education, culture, health, social welfare, transport, environment, and other expenditures.

Sample sizes per subgroup range from 33,780 to 274,421 (expenditure sample: 19,057 to 143,054) for Swiss citizens (Panel A); 12,330 to 57,557 (expenditure sample: 8,191 to 36,410) for permanent residents (Panel B); and 385 to 10,015 (expenditure sample: 228 to 6,339) for annual visa holders (Panel C).

Sources: Swiss Census 2000; community-level statistics on average tax rates, quality of life, house prices, and community expenditures (as described in the Data section of this paper); authors' own calculations. 
TABLE 5: Changes in Community Tax Rates and Internal Migration

A. Swiss citizens

\begin{tabular}{|c|c|c|c|c|c|c|}
\hline & $\begin{array}{c}(1) \\
\text { Earnings } \\
\text { interval and } \\
\text { tax level }\end{array}$ & $\begin{array}{c}(2) \\
\text { Household } \\
\text { characteristics }\end{array}$ & $\begin{array}{c}(3) \\
\text { Quality of life } \\
\end{array}$ & $\begin{array}{c}(4) \\
\text { House prices }\end{array}$ & $\begin{array}{c}(5) \\
\text { House prices } \\
\text { expenditure } \\
\text { sample } \\
\end{array}$ & $\begin{array}{c}(6) \\
\text { Community } \\
\text { expenditure }\end{array}$ \\
\hline No voc. age $21-35$ & $0.050 * *$ & $0.050 * *$ & $0.045 * *$ & $0.050 * *$ & $0.044 * *$ & $0.029 * *$ \\
\hline (s.e.) & $(0.004)$ & $(0.004)$ & $(0.004)$ & $(0.004)$ & $(0.006)$ & $(0.008)$ \\
\hline No voc. age $36-50$ & $0.016^{* *}$ & $0.016^{* *}$ & $0.015 * *$ & $0.019 * *$ & $0.023 * *$ & $0.012 * *$ \\
\hline (s.e.) & $(0.002)$ & $(0.002)$ & $(0.002)$ & $(0.002)$ & $(0.003)$ & $(0.004)$ \\
\hline No voc. age $51-64$ & -0.001 & 0.000 & 0.000 & $0.002 *$ & $0.004 *$ & -0.002 \\
\hline (s.e.) & $(0.001)$ & $(0.001)$ & $(0.001)$ & $(0.001)$ & $(0.002)$ & $(0.003)$ \\
\hline Voc. qual. age $21-35$ & $0.046^{* *}$ & $0.048 * *$ & $0.040 * *$ & $0.043 * *$ & $0.036 * *$ & $0.028 * *$ \\
\hline (s.e.) & $(0.002)$ & $(0.001)$ & $(0.002)$ & $(0.002)$ & $(0.002)$ & $(0.003)$ \\
\hline Voc. qual. age $36-50$ & $0.009 * *$ & $0.010 * *$ & $0.009 * *$ & $0.012 * *$ & $0.017 * *$ & $0.009 * *$ \\
\hline (s.e.) & $(0.001)$ & $(0.001)$ & $(0.001)$ & $(0.001)$ & $(0.001)$ & $(0.002)$ \\
\hline Voc. qual. age 51-64 & 0.001 & $0.001 * *$ & $0.002 * *$ & $0.004 * *$ & $0.005 * *$ & 0.003 \\
\hline (s.e.) & $(0.001)$ & $(0.001)$ & $(0.001)$ & $(0.001)$ & $(0.001)$ & $(0.002)$ \\
\hline College age $21-35$ & $0.073 * *$ & $0.078 * *$ & $0.071 * *$ & $0.072 * *$ & $0.065 * *$ & $0.033 * *$ \\
\hline (s.e.) & $(0.002)$ & $(0.002)$ & $(0.002)$ & $(0.002)$ & $(0.003)$ & $(0.005)$ \\
\hline College age $36-50$ & $0.015^{* *}$ & $0.017 * *$ & $0.016^{* *}$ & $0.018 * *$ & $0.026^{* *}$ & $0.009 * *$ \\
\hline (s.e.) & $(0.001)$ & $(0.001)$ & $(0.001)$ & $(0.001)$ & $(0.002)$ & $(0.002)$ \\
\hline College age 51-64 & $0.007 * *$ & $0.008 * *$ & $0.008 * *$ & $0.009 * *$ & $0.012 * *$ & $0.004^{*}$ \\
\hline (s.e.) & $(0.001)$ & $(0.001)$ & $(0.001)$ & $(0.001)$ & $(0.002)$ & $(0.002)$ \\
\hline
\end{tabular}

B. Permanent residents ( $\mathrm{C}$ permit $)$

\begin{tabular}{lcccccc}
\hline & $\begin{array}{c}(1) \\
\text { Earnings } \\
\text { interval and } \\
\text { tax level }\end{array}$ & $\begin{array}{c}(2) \\
\text { Household } \\
\text { characteristics }\end{array}$ & $\begin{array}{c}(3) \\
\text { Quality of life }\end{array}$ & $\begin{array}{c}(4) \\
\text { House prices }\end{array}$ & $\begin{array}{c}\text { House prices } \\
\text { expenditure } \\
\text { sample }\end{array}$ & $\begin{array}{c}\text { Community } \\
\text { expenditure }\end{array}$ \\
\hline No voc. age 21-35 & $0.042^{* *}$ & $0.042^{* *}$ & $0.028^{* *}$ & $0.032^{* *}$ & $0.028^{* *}$ & 0.006 \\
(s.e.) & $(0.003)$ & $(0.003)$ & $(0.003)$ & $(0.003)$ & $(0.004)$ & $(0.005)$ \\
No voc. age 36-50 & $0.014^{* *}$ & $0.014^{* *}$ & $0.008^{* *}$ & $0.010^{* *}$ & $0.009^{* *}$ & -0.002 \\
(s.e.) & $(0.001)$ & $(0.001)$ & $(0.001)$ & $(0.001)$ & $(0.002)$ & $(0.002)$ \\
No voc. age 51-64 & $0.006^{* *}$ & $0.005^{* *}$ & $0.003^{* *}$ & $0.003^{* *}$ & $0.005^{* *}$ & 0.002 \\
(s.e.) & $(0.001)$ & $(0.001)$ & $(0.001)$ & $(0.001)$ & $(0.002)$ & $(0.002)$ \\
\hline Voc. qual. age 21-35 & $0.067^{* *}$ & $0.010^{* *}$ & $0.009^{* *}$ & $0.053^{* *}$ & $0.057^{* *}$ & $0.033^{* *}$ \\
(s.e.) & $(0.003)$ & $(0.003)$ & $(0.003)$ & $(0.003)$ & $(0.005)$ & $(0.006)$ \\
Voc. qual. age 36-50 & $0.019^{* *}$ & $0.020^{* *}$ & $0.013^{* *}$ & $0.017^{* *}$ & $0.019^{* *}$ & 0.004 \\
(s.e.) & $(0.002)$ & $(0.002)$ & $(0.002)$ & $(0.002)$ & $(0.003)$ & $(0.004)$ \\
Voc. qual. age 51-64 & $0.007^{* *}$ & $0.007^{* *}$ & $0.005^{* *}$ & $0.007^{* *}$ & $0.005^{*}$ & -0.002 \\
(s.e.) & $(0.002)$ & $(0.002)$ & $(0.002)$ & $(0.002)$ & $(0.003)$ & $(0.003)$ \\
\hline College age 21-35 & $0.075^{* *}$ & $0.077^{* *}$ & $0.064^{* *}$ & $0.063^{* *}$ & $0.063^{* *}$ & 0.003 \\
(s.e.) & $(0.006)$ & $(0.005)$ & $(0.006)$ & $(0.006)$ & $(0.009)$ & $(0.013)$ \\
College age 36-50 & $0.036^{* *}$ & $0.035^{* *}$ & $0.028^{* *}$ & $0.029^{* *}$ & $0.037^{* *}$ & 0.009 \\
(s.e.) & $(0.003)$ & $(0.003)$ & $(0.003)$ & $(0.003)$ & $(0.005)$ & $(0.007)$ \\
College age 51-64 & $0.008^{* *}$ & $0.008^{* *}$ & $0.006^{* *}$ & $0.008^{* *}$ & $0.015^{* *}$ & -0.001 \\
(s.e.) & $(0.003)$ & $(0.003)$ & $(0.003)$ & $(0.003)$ & $(0.004)$ & $(0.006)$ \\
\hline
\end{tabular}


C. Annual visa holders (B permit)

\begin{tabular}{lcccccc}
\hline & $\begin{array}{c}(1) \\
\text { Earnings } \\
\text { interval and } \\
\text { tax level }\end{array}$ & $\begin{array}{c}(2) \\
\text { Household } \\
\text { characteristics }\end{array}$ & $\begin{array}{c}(3) \\
\text { Quality of life }\end{array}$ & $\begin{array}{c}(4) \\
\text { House prices }\end{array}$ & $\begin{array}{c}(5) \\
\text { House prices } \\
\text { expenditure } \\
\text { sample }\end{array}$ & $\begin{array}{c}\text { Community } \\
\text { expenditure }\end{array}$ \\
\hline No voc. age 21-35 & $0.020^{* *}$ & $0.022^{* *}$ & $0.011^{*}$ & $0.014^{* *}$ & 0.011 & 0.010 \\
(s.e.) & $(0.006)$ & $(0.006)$ & $(0.006)$ & $(0.007)$ & $(0.009)$ & $(0.013)$ \\
No voc. age 36-50 & $0.011^{* *}$ & $0.012^{* *}$ & 0.003 & 0.005 & -0.003 & 0.003 \\
(s.e.) & $(0.005)$ & $(0.005)$ & $(0.005)$ & $(0.005)$ & $(0.006)$ & $(0.008)$ \\
No voc. age 51-64 & $0.018^{*}$ & $0.016^{*}$ & 0.010 & 0.009 & 0.003 & 0.000 \\
(s.e.) & $(0.009)$ & $(0.009)$ & $(0.008)$ & $(0.008)$ & $(0.006)$ & $(0.000)$ \\
\hline Voc. qual. age 21-35 & $0.031^{* *}$ & $0.018^{*}$ & 0.012 & $0.030^{* *}$ & $0.031 * *$ & 0.000 \\
(s.e.) & $(0.010)$ & $(0.009)$ & $(0.010)$ & $(0.010)$ & $(0.013)$ & $(0.016)$ \\
Voc. qual. age 36-50 & 0.013 & $0.018^{* *}$ & 0.012 & $0.016^{*}$ & 0.014 & 0.021 \\
(s.e.) & $(0.009)$ & $(0.008)$ & $(0.008)$ & $(0.009)$ & $(0.011)$ & $(0.018)$ \\
Voc. qual. age 51-64 & 0.015 & 0.018 & 0.015 & 0.018 & 0.025 & 0.004 \\
(s.e.) & $(0.021)$ & $(0.019)$ & $(0.020)$ & $(0.021)$ & $(0.024)$ & $(0.011)$ \\
\hline College age 21-35 & $0.093^{* *}$ & $0.099^{* *}$ & $0.083^{* *}$ & $0.074 * *$ & $0.062^{* *}$ & 0.019 \\
(s.e.) & $(0.011)$ & $(0.011)$ & $(0.012)$ & $(0.013)$ & $(0.016)$ & $(0.032)$ \\
College age 36-50 & $0.042^{* *}$ & $0.047^{* *}$ & $0.039^{* *}$ & $0.040^{* *}$ & $0.050^{* *}$ & 0.019 \\
(s.e.) & $(0.009)$ & $(0.009)$ & $(0.009)$ & $(0.010)$ & $(0.013)$ & $(0.026)$ \\
College age 51-64 & $0.050^{* *}$ & $0.046^{* *}$ & $0.032^{*}$ & $0.031^{*}$ & 0.016 & -0.007 \\
(s.e.) & $(0.016)$ & $(0.016)$ & $(0.016)$ & $(0.017)$ & $(0.020)$ & $(0.043)$ \\
\hline
\end{tabular}

Notes: ** (*) indicates statistical significance at the 5 percent (10 percent) level. Reported estimates refer to the effect at the sample mean of a marginal increase in tax rate change (between the 1995 and 2000 tax rates in the 1995 community of residence) on the probability to migrate. Estimates are obtained from logit regressions. Displayed standard errors for the marginal effects are calculated using the delta method. In column (1), we control for predicted earnings using dummy variables for any of eleven earnings intervals. We also control for levels of the average tax rate. In column (2), the additional control variables are age, gender, marital status, and number of children in 1995. In column (3), we additionally control for the 1996 Walter-Busch (1997) quality of life index in the 1995 community of residence. We also add in the number of inhabitants in the 1995 community of residence. In column (4), we add in Wüest and Partner's offered house prices for the year 2000 in the 1995 community of residence. In column (5), we estimate the same regression as in column (4) but using the restricted sample for which community expenditure data are available. In column (6), we add in the levels of 1995 community expenditures and the difference between 1995 and 2000 community expenditures for the 1995 community of residence. We include nine different expenditure types, referring to general administration, law and order, education, culture, health, social welfare, transport, environment, and other expenditures.

Sample sizes per subgroup range from 33,636 to 274,271 (expenditure sample: 18,956 to 142,961) for Swiss citizens (Panel A); 12,329 to 57,443 (expenditure sample: 8,190 to 36,319 ) for permanent residents (Panel B); and 385 to 9,971 (expenditure sample: 228 to 6,298) for annual visa holders (Panel C).

Sources: Swiss Census 2000; community-level statistics on average tax rates, quality of life, house prices, and community expenditures (as described in the Data section of this paper); authors' own calculations. 
TABLE 6: Changes in Community Taxes 1990-1995 and Internal Migration

Swiss Citizens

\begin{tabular}{lcccccc}
\hline & $\begin{array}{c}(1) \\
\text { Earnings } \\
\text { interval and } \\
\text { tax level }\end{array}$ & $\begin{array}{c}\text { Household } \\
\text { characteristics }\end{array}$ & $\begin{array}{c}(3) \\
\text { Quality of life }\end{array}$ & $\begin{array}{c}(4) \\
\text { House prices }\end{array}$ & $\begin{array}{c}(5) \\
\text { House prices } \\
\text { expenditure } \\
\text { sample }\end{array}$ & $\begin{array}{c}\text { Community } \\
\text { expenditure }\end{array}$ \\
\hline No voc. age 21-35 & $0.017^{* *}$ & $0.017^{* *}$ & $0.016^{* *}$ & $0.017^{* *}$ & $0.021^{* *}$ & $0.014^{* *}$ \\
(s.e.) & $(0.002)$ & $(0.002)$ & $(0.002)$ & $(0.002)$ & $(0.003)$ & $(0.003)$ \\
No voc. age 36-50 & $0.008^{* *}$ & $0.008^{* *}$ & $0.009^{* *}$ & $0.009^{* *}$ & $0.013^{* *}$ & $0.011^{* *}$ \\
(s.e.) & $(0.001)$ & $(0.001)$ & $(0.001)$ & $(0.001)$ & $(0.001)$ & $(0.002)$ \\
No voc. age 51-64 & $0.004^{* *}$ & $0.004^{* *}$ & $0.004^{* *}$ & $0.004^{* *}$ & $0.007^{* *}$ & $0.006^{* *}$ \\
(s.e.) & $(0.001)$ & $(0.001)$ & $(0.001)$ & $(0.001)$ & $(0.001)$ & $(0.001)$ \\
\hline Voc. qual. age 21-35 & $0.020^{* *}$ & $0.020^{* *}$ & $0.019^{* *}$ & $0.020^{* *}$ & $0.025^{* *}$ & $0.016^{* *}$ \\
(s.e.) & $(0.001)$ & $(0.001)$ & $(0.001)$ & $(0.001)$ & $(0.001)$ & $(0.001)$ \\
Voc. qual. age 36-50 & $0.009^{* *}$ & $0.009^{* *}$ & $0.009^{* *}$ & $0.010^{* *}$ & $0.015^{* *}$ & $0.012^{* *}$ \\
(s.e.) & $(0.000)$ & $(0.000)$ & $(0.000)$ & $(0.000)$ & $(0.001)$ & $(0.001)$ \\
Voc. qual. age 51-64 & $0.005^{* *}$ & $0.005^{* *}$ & $0.004^{* *}$ & $0.005^{* *}$ & $0.007^{* *}$ & $0.006^{* *}$ \\
(s.e.) & $(0.000)$ & $(0.000)$ & $(0.000)$ & $(0.000)$ & $(0.001)$ & $(0.001)$ \\
\hline College age 21-35 & $0.028^{* *}$ & $0.029^{* *}$ & $0.027^{* *}$ & $0.027^{* *}$ & $0.037^{* *}$ & $0.029^{* *}$ \\
(s.e.) & $(0.001)$ & $(0.001)$ & $(0.001)$ & $(0.001)$ & $(0.002)$ & $(0.002)$ \\
College age 36-50 & $0.009^{* *}$ & $0.010^{* *}$ & $0.010^{* *}$ & $0.010^{* *}$ & $0.017^{* *}$ & $0.012^{* *}$ \\
(s.e.) & $(0.001)$ & $(0.001)$ & $(0.001)$ & $(0.001)$ & $(0.001)$ & $(0.001)$ \\
College age 51-64 & $0.004^{* *}$ & $0.004^{* *}$ & $0.004^{* *}$ & $0.005^{* *}$ & $0.006^{* *}$ & $0.005^{* *}$ \\
(s.e.) & $(0.001)$ & $(0.001)$ & $(0.001)$ & $(0.001)$ & $(0.001)$ & $(0.001)$ \\
\hline N. & &
\end{tabular}

Notes: ** $(*)$ indicates statistical significance at the $5 \%(10 \%)$ level. Reported estimates refer to the effect at the sample mean of a marginal increase in tax rate change (between the 1990 and 1995 tax rates in the 1995 community of residence) on the probability of migration. Estimates are obtained from logit regressions. Displayed standard errors for the marginal effects are calculated using the delta method. In column (1), we control for predicted earnings using dummy variables for any of eleven earnings intervals. We also control for levels of the average tax rate. In column (2), the additional control variables are age, gender, marital status, and number of children in 1995. In column (3), we additionally control for the 1996 Walter-Busch (1997) quality of life index in the 1995 community of residence. We also add in the number of inhabitants in the 1995 community of residence. In column (4), we add in Wüest and Partner's offered house prices for the year 2000 in the 1995 community of residence. In column (5), we estimate the same regression as in column (4) but using the restricted sample for which community expenditure data are available. In column (6), we add in the 1995 levels of community expenditures in the 1995 community of residence. We include nine different expenditure types, referring to general administration, law and order, education, culture, health, social welfare, transport, environment, and other expenditures.

Sample sizes per subgroup range from 32,915 to 265,259 (expenditure sample: 19,057 to 143,054) for Swiss citizens (Panel A); 12,120 to 56,521 (expenditure sample: 8,191 to 36,410) for permanent residents (Panel B); and 374 to 9,786 (expenditure sample: 228 to 6,339) for annual visa holders (Panel C).

Sources: Swiss Census 2000; community-level statistics on average tax rates, quality of life, house prices, and community expenditures (as described in the Data section of this paper); authors' own calculations. 
TABLE 7: Internal Migration Rates and Changes in Community Tax Rates 2000-2005

All Residents

\begin{tabular}{|c|c|c|c|c|c|c|}
\hline & $\begin{array}{c}(1) \\
\text { Earnings } \\
\text { interval and } \\
\text { tax level }\end{array}$ & $\begin{array}{c}(2) \\
\text { Household } \\
\text { characteristics }\end{array}$ & $\begin{array}{c}\text { (3) } \\
\text { Quality of life } \\
\end{array}$ & $\begin{array}{c}(4) \\
\text { House prices }\end{array}$ & $\begin{array}{c}(5) \\
\text { House prices } \\
\text { expenditure } \\
\text { sample }\end{array}$ & $\begin{array}{c}\text { (6) } \\
\text { Community } \\
\text { expenditure }\end{array}$ \\
\hline No voc. age $21-35$ & 12.3 & 14.0 & 1.8 & 1.6 & 24.2 & 15.3 \\
\hline (s.e.) & $(16.7)$ & $(16.9)$ & (19.9) & $(20.2)$ & $(29.3)$ & $(29.0)$ \\
\hline No voc. age $36-50$ & -27.2 & -29.8 & -21.1 & -19.5 & 28.5 & 42.5 \\
\hline (s.e.) & $(21.4)$ & $(20.9)$ & $(23.8)$ & $(23.8)$ & $(58.2)$ & $(54.0)$ \\
\hline No voc. age 51-64 & 15.7 & 22.2 & 22.2 & 17.2 & -68.0 & $-101.1^{*}$ \\
\hline (s.e.) & $(29.6)$ & $(29.2)$ & $(37.3)$ & $(37.3)$ & $(53.8)$ & $(57.7)$ \\
\hline Voc. qual. age $21-35$ & 2.2 & -2.8 & 0.4 & 0.2 & $20.7 * *$ & $15.7 * *$ \\
\hline (s.e.) & $(5.0)$ & (5.1) & $(5.2)$ & $(5.2)$ & $(7.9)$ & $(7.9)$ \\
\hline Voc. qual. age $36-50$ & -10.5 & -12.2 & -13.4 & -12.1 & -14.2 & -3.4 \\
\hline (s.e.) & $(10.6)$ & $(10.7)$ & $(11.7)$ & $(11.7)$ & $(25.9)$ & $(27.7)$ \\
\hline Voc. qual. age 51-64 & -8.5 & 16.8 & 19.9 & 20.2 & -59.0 & -46.3 \\
\hline (s.e.) & $(17.7)$ & $(18.3)$ & $(20.6)$ & $(20.6)$ & $(44.5)$ & $(44.6)$ \\
\hline College age $21-35$ & $32.1 * *$ & $29.0 * *$ & $27.7 * *$ & $26.3 * *$ & 22.0 & 24.3 \\
\hline (s.e.) & $(10.9)$ & $(9.3)$ & $(9.2)$ & $(9.0)$ & $(16.3)$ & $(18.2)$ \\
\hline College age $36-50$ & 14.4 & 18.0 & 19.5 & 21.4 & 14.5 & 9.8 \\
\hline (s.e.) & $(12.6)$ & $(11.3)$ & $(12.5)$ & $(12.4)$ & (19.1) & $(21.2)$ \\
\hline College age $51-64$ & -20.8 & 1.8 & 2.5 & 6.4 & -51.5 & -33.5 \\
\hline (s.e.) & $(25.6)$ & $(24.8)$ & $(26.7)$ & $(26.8)$ & $(39.5)$ & $(50.8)$ \\
\hline
\end{tabular}

Notes: ** $(*)$ indicates statistical significance at the $5 \%(10 \%)$ level. Displayed coefficients of the community outmigration rate (between 1995 and 2000) are obtained from weighted least squares regressions using community size as weights. All variables are community sample means. In column (1), we control for predicted earnings. We also control for levels of the average tax rate in 2000. In column (2), the additional control variables are age, gender, marital status, and number of children in 2000. In column (3), we additionally control for the 1996 Walter-Busch (1997) quality of life index. We also add in the number of inhabitants in the 2000 community of residence. In column (4), we add in Wüest and Partner's offered house prices for the year 2000. In column (5), we estimate the same regression as in column (4) but using the restricted sample for which community expenditure data are available. In column (6), we add in the 2000 levels of community expenditures. We include nine different expenditure types, referring to general administration, law and order, education, culture, health, social welfare, transport, environment, and other expenditures.

Community sample sizes per subgroup are 726 in columns (1) and (2), 630 in columns (3) and (4), and 132 in columns (5) and (6) (expenditure samples).

Sources: Swiss Census 2000; community-level statistics on average tax rates, quality of life, house prices, and community expenditures (as described in the Data section of this paper); author's own calculations. 